\title{
Siberian environmental change: Synthesis of recent studies and opportunities for networking
}

\author{
Terry V. Callaghan, Olga Shaduyko, Sergey N. Kirpotin, \\ Evgeny Gordov
}

Published online: 29 September 2021

\begin{abstract}
A recent multidisciplinary compilation of studies on changes in the Siberian environment details how climate is changing faster than most places on Earth with exceptional warming in the north and increased aridity in the south. Impacts of these changes are rapid permafrost thaw and melt of glaciers, increased flooding, extreme weather events leading to sudden changes in biodiversity, increased forest fires, more insect pest outbreaks, and increased emissions of $\mathrm{CO}_{2}$ and methane. These trends interact with sociological changes leading to land-use change, globalisation of diets, impaired health of Arctic Peoples, and challenges for transport. Local mitigation and adaptation measures are likely to be limited by a range of public perceptions of climate change that vary according to personal background. However, Siberia has the possibility through land surface feedbacks to amplify or suppress climate change impacts at potentially global levels. Based on the diverse studies presented in this Ambio Special Issue, we suggest ways forward for more sustainable environmental research and management.
\end{abstract}

Keywords Biodiversity biogeochemistry .

Ecosystem services - Environmental change $\cdot$ Siberia .

Societies

\section{INTRODUCTION}

The Anthropocene (Steffen 2021) is presenting the global community with many challenges. Among these are food security, biodiversity conservation, sustaining water

Supplementary Information The online version contains supplementary material available at https://doi.org/10.1007/s13280021-01626-7. resources, and climate change. Responding to these and other challenges, the United Nations has formulated sustainable development goals (Jensen 2021). To achieve these goals, it is imperative to explore the challenges and opportunities within the world's largest continent, Eurasia, and particularly within its largest landmass, Siberia. Siberia is not only important because of its size; it has vast fresh water, mineral, fossil fuel, soil, forest, and biodiversity resources as well as huge possibilities for agricultural and biofuel production - and it interacts with global climate.

Siberia stretches $7500 \mathrm{~km}$ from the Ural Mountains in the west to the Pacific coast in the east. Its area is 13.1 million $\mathrm{km}^{2}$ yet its population density is low with only 36 million people. It contains a great diversity of people, settlements, environments, biomes, and land forms stretching from semi-desert in the south, through glaciated mountains, steppes, and taiga, to tundra and polar desert in the north, all connected through major river systems (Table 1, Fig. 1).

Many aspects of society and environment are changing in Siberia with some changes, such as climate, being some of the most rapid on Earth. However, because of a sparse population, few major urban centres scattered over vast distances, and generally isolated and remote regions, Siberia is somewhat understudied and much of the expertise and knowledge — both science and Indigenous—resides within Russia, is written in the Russian language, and is largely unavailable in the West (e.g. Callaghan et al. 2021a).

To enhance data collection, gather Indigenous Knowledge and increase the global awareness of Siberian environmental change, various international, multidisciplinary networking activities have developed. For example, the 


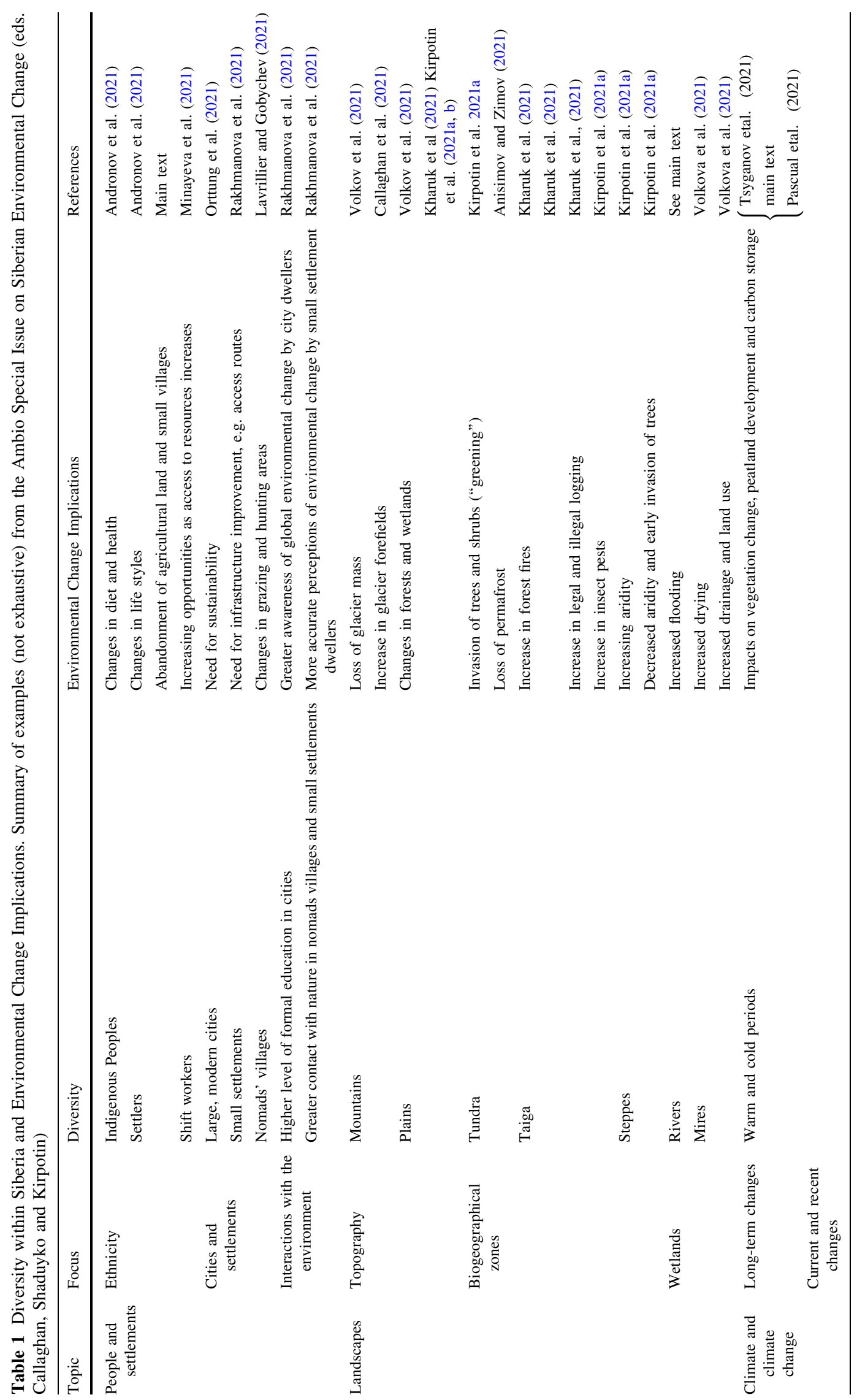




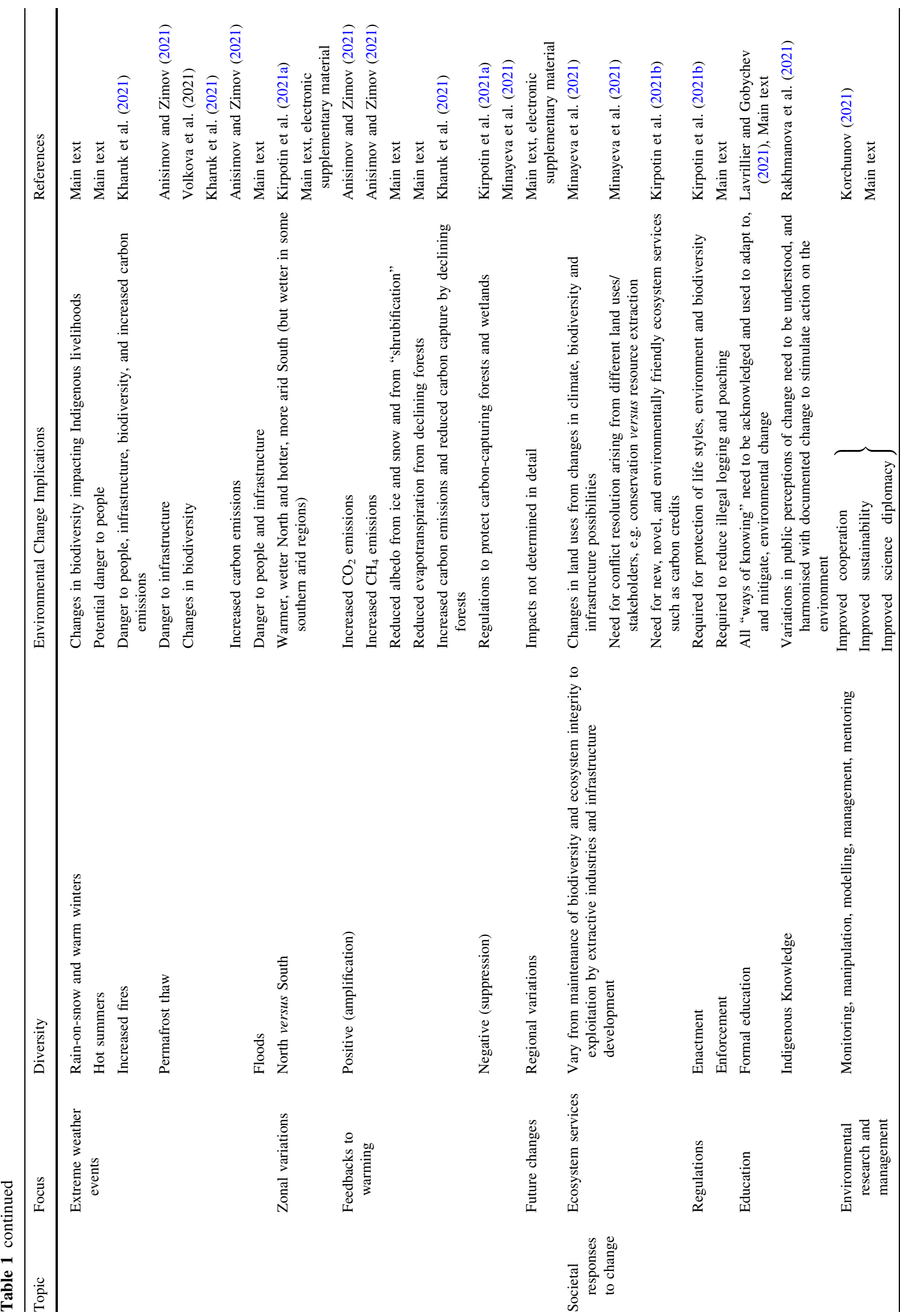


"Northern Eurasia Earth Science Partnership Initiative" (NEESPI ${ }^{1}$ ) seeks to develop "a better understanding of the interactions between the ecosystem, atmosphere, and human dynamics in northern Eurasia in support of international science programs with particular relevance to Global climate change research interests and government agency funding priorities", and the "Snowchange Cooperative" has developed citizen science programmes among the Arctic Peoples of northern Eurasia. ${ }^{2}$ The EU-funded "INTERACT" projects have networked 89 northern research stations, 18 of which are in Siberia (Fig. 2; Callaghan et al. 2015). INTERACT offers "transnational access" whereby about 1000 scientists have received grants to visit research stations beyond their national borders (11 stations in Siberia). Recently, four Siberian stations have been funded to participate in "virtual access" with a single entry point through which their data are made freely available to applicants. ${ }^{3}$ As a result of INTERACT's activities, a new Siberian network was established in 2016-the "Siberian Environmental Change Network" (Callaghan et al. 2020a).

The Siberian Environmental Change Network (SecNet) links 17 institutions, 23 research stations, 300 research sites (Fig. 2), many researchers, decision makers, and Indigenous Peoples and welcomes collaboration. "By accumulating experience and knowledge on Siberian environments and society", SecNet "seeks to understand and predict societally important changes so that negative anthropogenic consequences can be minimised". Both SecNet and INTERACT provide key connections to the practicality and science of collaborative research in Siberia.

The Special Issue on Siberian Environmental Change (Callaghan et al. (eds.) 2021b) is one of the SecNet activities and is also a cooperation with INTERACT: bringing together the Siberian research community to document for the global community the diversity of environmental changes currently occurring throughout this vast landmass (Table 1). To achieve this, 93 (mostly Russian) researchers contributed to 13 papers. Also, Ambassador Korchunov, Chair of the Senior Arctic Officials of the Arctic Council, has provided a Preface (Korchunov 2021), highlighting the importance of the overall study. Although there is a strong focus on Western Siberia, some aspects of the Special Issue cover much of the geographical variability of the wider concept of Siberia (Table 1).

Thematically, the studies focus on

- Societal issues such as the sustainability of Arctic cities (Orttung et al. 2021), changing diet and health of

\footnotetext{
${ }^{1}$ https://neespi.org

2 www.snowchange.org

${ }^{3}$ www.eu-interact.org; https://dataportal.eu-interact.org

${ }^{4}$ www.secnet.online
}

Indigenous People (Andronov et al. 2021), varying perceptions of climate change (Rakhmanova et al. 2021) and Indigenous knowledge (Lavrillier and Gabyshev 2021);

- biodiversity changes throughout Siberia (Kirpotin et al. 2021a), in the forests (Kharuk et al. 2021) and in the southern mountains (Volkov et al. 2021; Volkova et al. 2021);

- historical development of peatlands, peatland ecosystem function, and carbon storage (Pascual et al. 2021; Tsyganov et al. 2021; Kirpotin et al. 2021b).

- thawing permafrost and carbon emissions (Anisimov and Zimov 2021);

- management of ecosystem services (Minayeva et al. 2021).

In this synthesis paper, we aim to present a general and accessible overview of these studies and to increase global awareness of a) the environmental changes in Siberia, b) their likely local and global consequences and opportunities, and c) the scientific and Indigenous expertise, data, and networking activities within SecNet to stimulate international research and networking on topics of local, national, and global importance. We also review and add to earlier recommendations for enhancing dialogue between researchers, Indigenous People, and Decision Makers (Callaghan et al. 2020b), and we describe a conceptual model for sustainable environmental research and management.

\section{DIVERSITY WITHIN SIBERIA}

Siberia is diverse: even definitions of Siberia are diverse. Some sources (e.g. Shumilova 1962) separate continental Siberia from the Far East which has a monsoon climate regime. The border between Siberia and the Far East is the watershed along the mountain ranges: the Kolyma Upland, the Koryak Upland, the eastern edge of the Chersky Ridge, the Dzhugdzhur Ridge, and the Stanovoy Ridge, ending at the border with China. In this synthesis, we consider both regions as Siberia, i.e. from the Ural Mountains in the west to the Pacific Ocean in the east. Latitudinally, Siberia stretches from the Altai-Sayan Mountains on the borders with Mongolia, China, and Kazakhstan in the south to the Arctic coast and islands. Siberia is home to a diversity of people that have originated from four fundamental waves of migration: millennial establishment of Indigenous Peoples, Russian settlers from the sixteenth century, Soviet-era influx of industrial workers, and post-Soviet resettlement of people out-migrating from Siberia and moving from rural to urban areas (Naumov and Collins 2006; Ignatova 2017; Loginov et al. 2020). This has led to the current great 
(a)

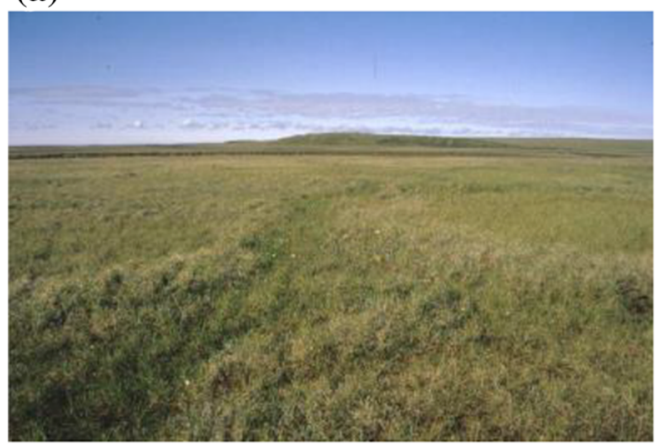

(c)

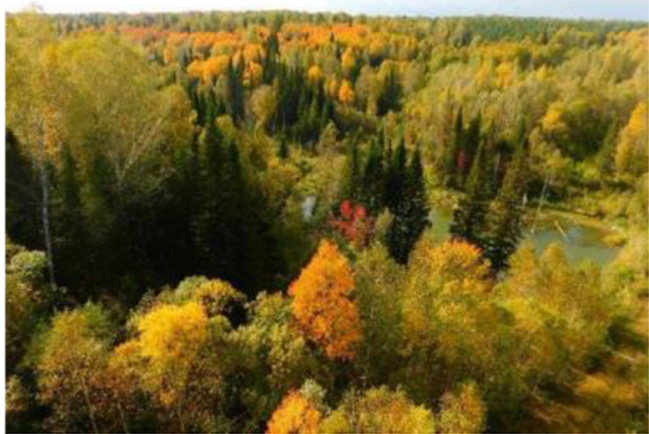

(e)

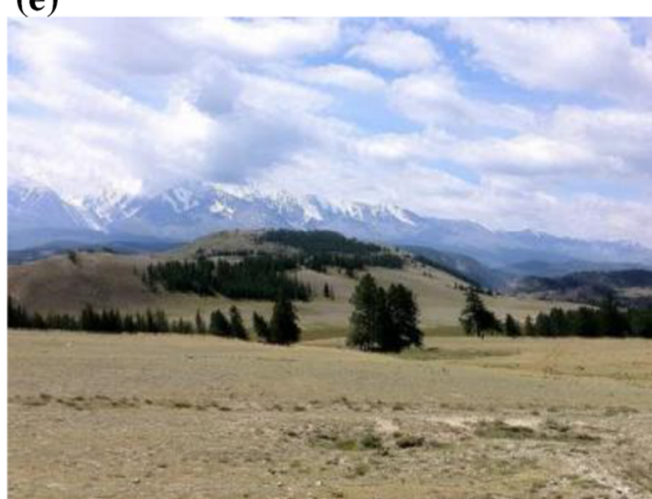

(g)

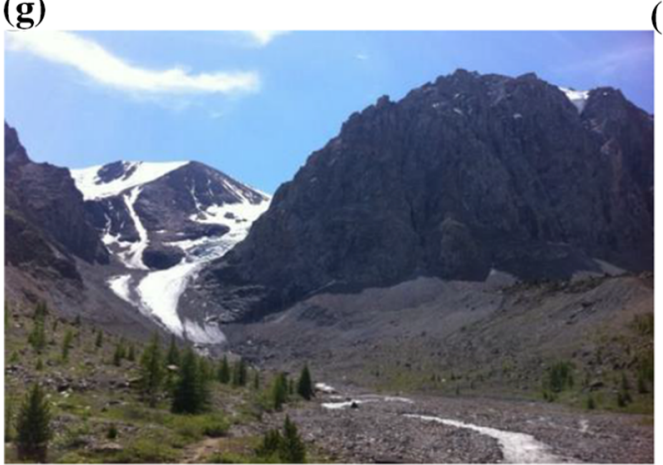

(b)

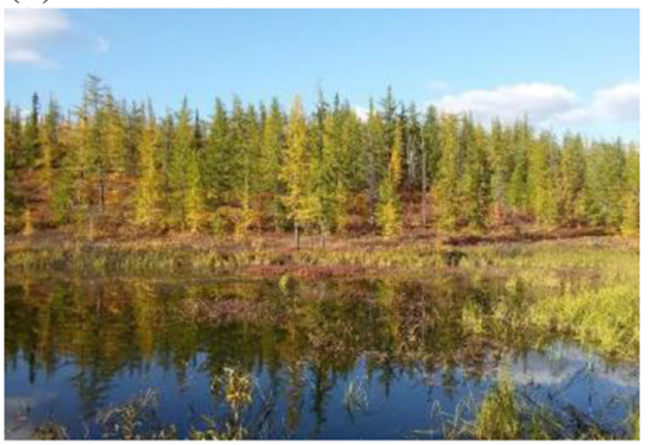

(d)

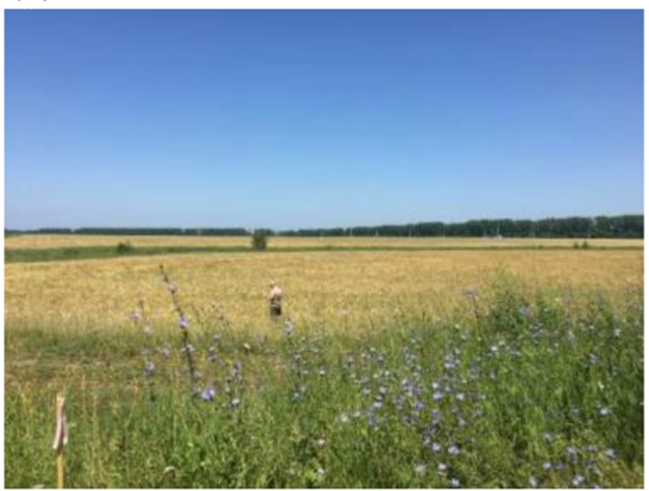

(f)

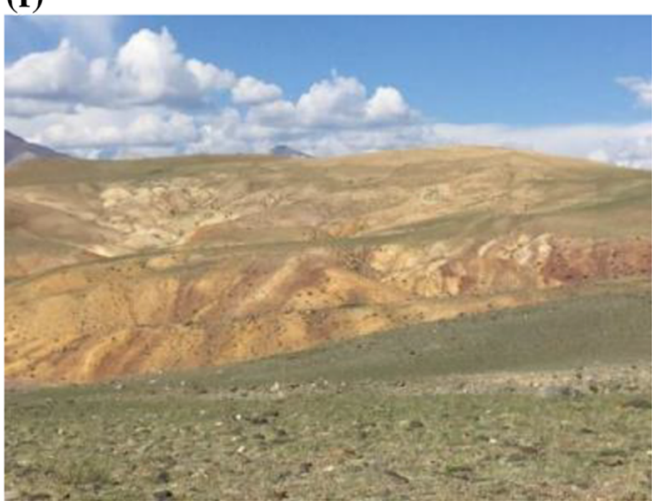

(h)

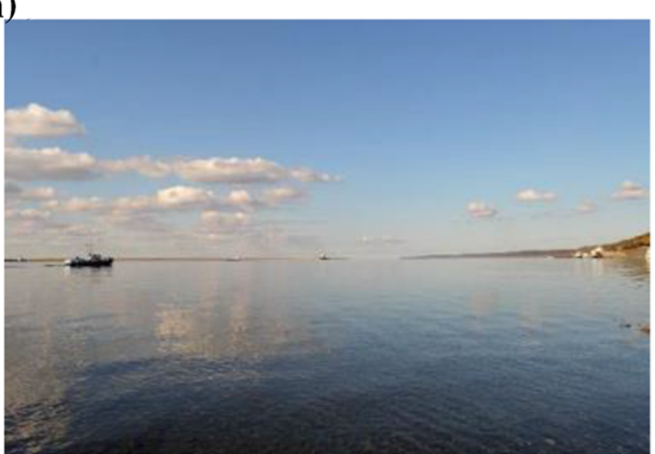

Fig. 1 Diversity of landscape types in Siberia. a The graminoid tundra of the Yana delta (low polygon centres, ridges, and troughs can be seen) b northern taiga, Taimyr c "chern" (dense, waterlogged) southern taiga, Salair Ridge, Western Siberia d forest steppes converted to grain growing areas, near Barnaul, e dry-steppes, Kuraiskiy Steppe, Altai Republic, south Siberia f semi-desert, Kyzyl-Chin gorge in the Chuya intermontane basin near the Mongolian border $\mathbf{g}$ Alpine and glacial landscapes, Aktru, Altai Mountains h Yenisey river, Dudinka area. Photo credits: (a, d, e, f, g) T.V. Callaghan (b, c, h) S.N. Kirpotin 


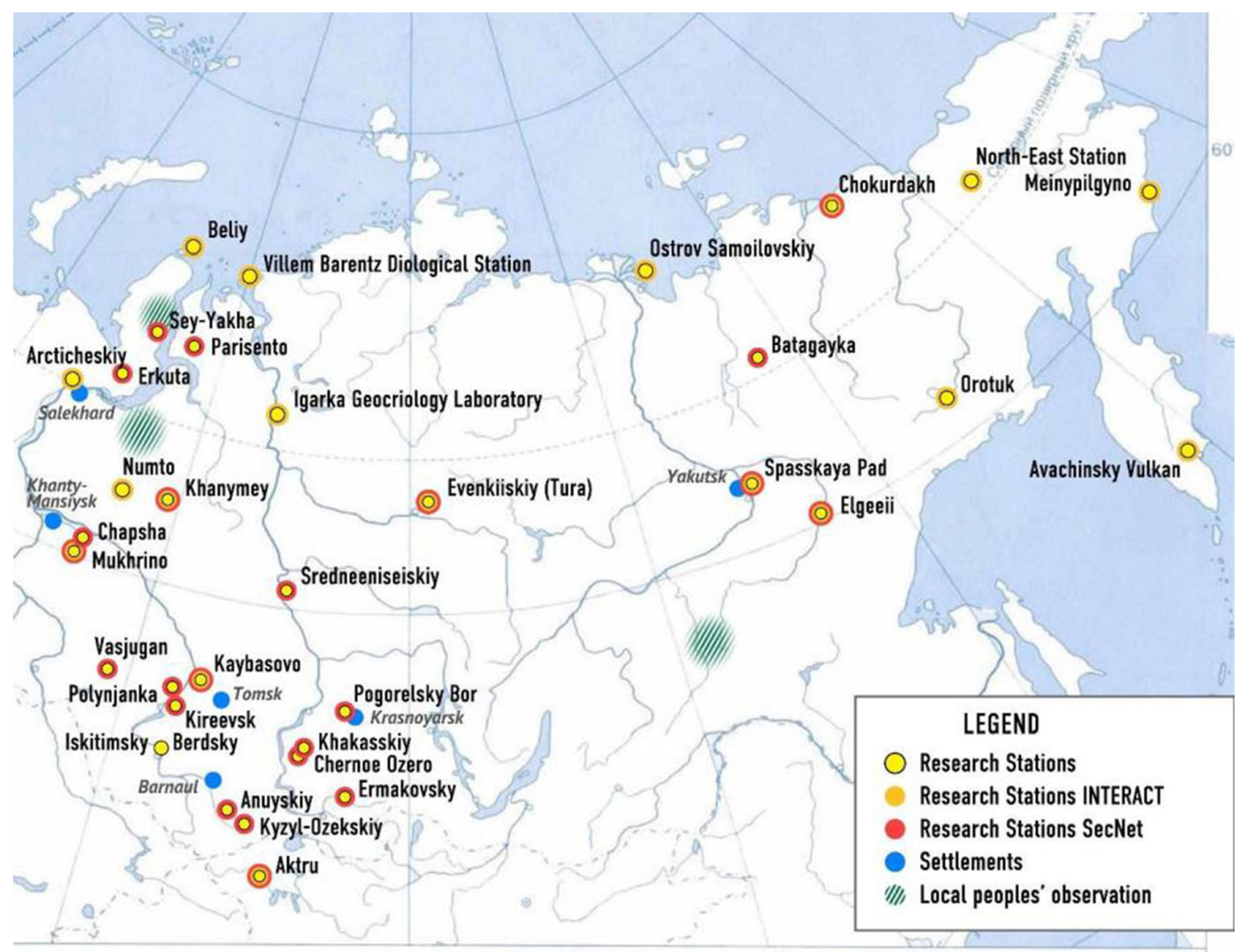

Fig. 2 SecNet and INTERACT research stations and sites, and centres of Indigenous Knowledge used in the study

diversity of settlement types that range from nomad homes to great industrial and modern cites (Orrtung et al. 2021; Rakhmanova et al. 2021; Table 1, Fig. 3).

This huge diverse land mass and its numerous economic resources are both experiencing local environmental changes and contributing to changes of even global significance. As situated in the middle of the world's largest continent, Siberia presents a natural laboratory in which different global climatic processes interact with regional climate processes and feedbacks to determine regional climate variability and dynamics. As this territory contains a significant part of the Earth's land, biosphere and cryosphere, and fresh water, its interactions with the global atmospheric and oceanic circulations contribute significantly to the state of our global climate and its dynamics, for example, in the mid-latitudes (Cohen et al. 2019). Many of the diverse changes (Table 1) are leading to societal challenges but not all: some offer opportunities, at least in the short term.

\section{DIFFERENT WAYS OF KNOWING}

In a rapidly changing environment, it is essential to know what is changing, what is causing the changes, what are the implications of the changes and how to respond. In this wide context, "knowing" is multi-faceted. Traditional western science approaches have been used in this Special Issue, e.g. measurement and modelling (Anisimov and Zimov 2021) and remote sensing (Minayeva et al. 2021). Long-term data collection and observations by researchers local to Siberia (Kirpotin et al. 2021a), often with expertise in specific taxonomic groups that are rare globally (Volkova et al. 2021), have provided invaluable datasets previously archived only locally. Indigenous Knowledge has also provided insights into neglected processes occurring in remote regions (Lavrillier and Gabichev 2021). At the same time, social science approaches have been used to explore what people think they know and how these perceptions are moulded by local experiences and personal backgrounds (Rakhmanova et al. 2021). All of these ways of knowing are valid sources of information. Without each aspect, it is impossible to understand important processes in locations that are remote and largely inaccessible, and variations over vast, poorly populated territories. Also, integrating each way of knowing is important to assess and validate models of future environmental changes and their implications from local to global levels. 
(a)

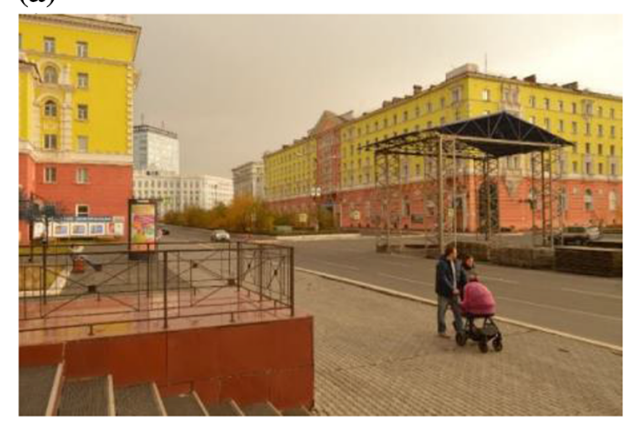

(c)

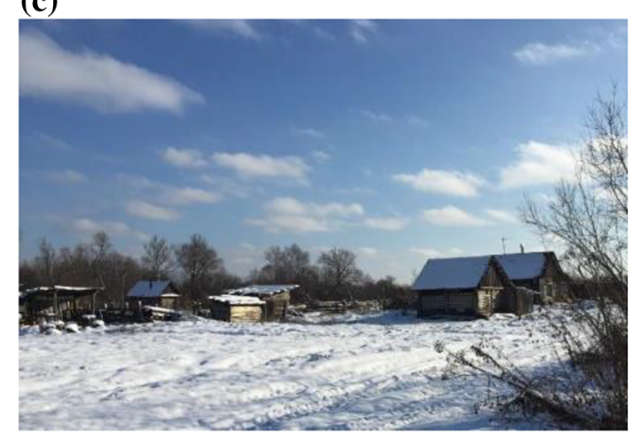

(e)

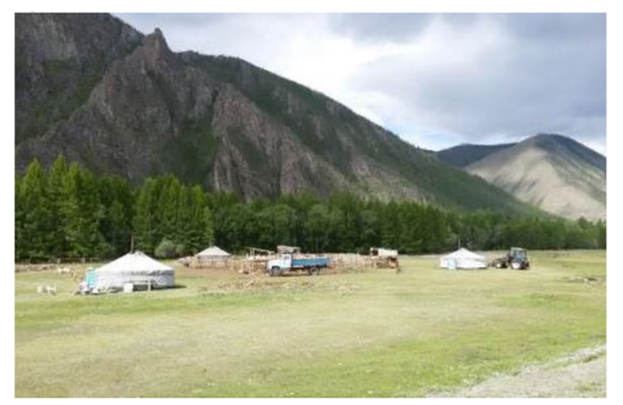

(b)

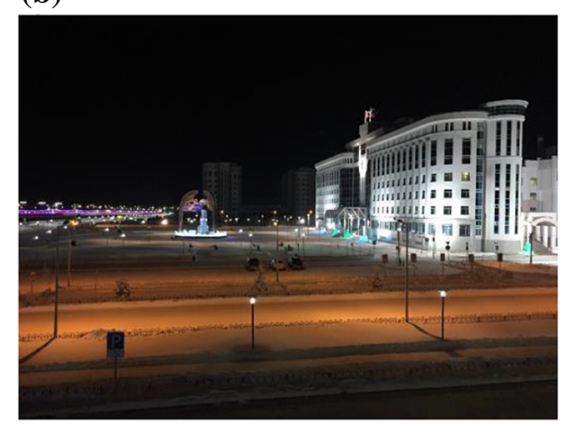

(d)

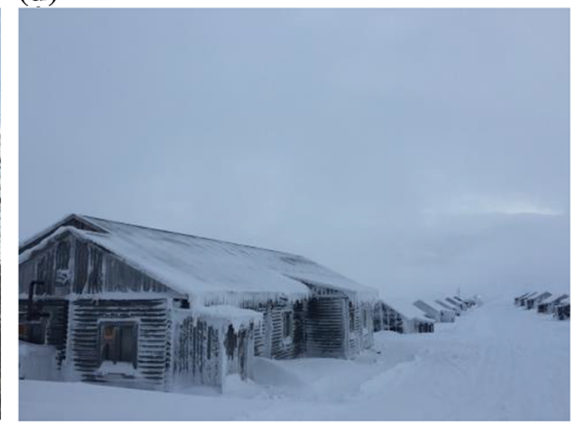

(f)

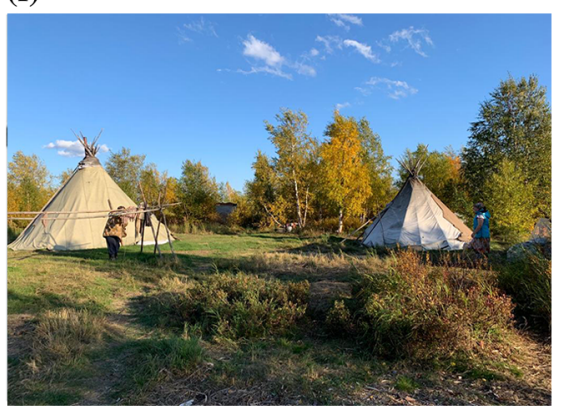

Fig. 3 Diversity of Siberian settlements. a The modern industrial city of Norilsk; $\mathbf{b}$ the administrative centre of the Yamal-Nenets Autonmous Region, Salekhard; c Partly abandoned small farming village, Kaibasovo, southern taiga; d Harbey tungsten- molybdenum mining village for shift workers, Priural'skiy district, Polar Urals; e Nomadic yurts in the Western Sayan Mountains at Khakassia, in the South of Siberia; f Nomadic chums in the Yamal-Nenets Autonomous Region. Photo credits: (a, e) S.N. Kirpotin, (b-d, f) T.V. Callaghan

One of the keys to maximise the use of different knowledge types is to network as in SecNet, and INTERACT, the bases for this study.

\section{THE DIVERSITY AND COMPLEXITY OF CLIMATE CHANGES}

The environment of Siberia has been changing over long time periods (Tsyganov et al. 2021), and modern changes should be seen in that context. During the past 10 000 years, the climate of Siberia varied significantly, with both warm and cold periods (Groisman et al. 2013). During the past century, Siberia became much warmer and the cold season precipitation north of $55^{\circ} \mathrm{N}$ increased. However, as there has been no rainfall increase over most of Siberia, summers have become drier with increased possibility of droughts in central and southern Siberia. Analysis of borehole temperature measurements reveals a total warming for southwest Siberia over the recent past five centuries of about $0.95 \pm 0.45^{\circ} \mathrm{C}$, with more than $75 \%\left(0.70{ }^{\circ} \mathrm{C}\right)$ occurring in the last two centuries (Pollack et al. 2003). However, in northeast Siberia, warming only started in the twentieth century, reaching about $0.67 \pm 0.21{ }^{\circ} \mathrm{C}$.

Due to nonlinear interactions between regional and global scales in the coupled climate system, the whole 
Arctic and its Siberian part have become hot spots of current climate change. The warming trend observed and modelled is three times as fast in the Arctic as the global average, ${ }^{5}$ due in part to a phenomenon called "Arctic amplification". This increasing surface air temperature is caused by sea-ice loss in the Arctic Ocean (Dai et al. 2019) that reached record levels in 2020/2021 due to increased ice export caused by high winds (Mallett et al. 2021). Arctic amplification can force regional responses in midlatitude weather (Cohen et al. 2019) demonstrating the global connectivity and importance of the Arctic and Siberia. For example, recent break down of the Arctic Vortex (rapid, anti-clockwise winds around the Arctic) has caused low temperatures in the UK and US. The first observers of local climate change, the people who live close to nature, particularly the Indigenous People, see weather changes and their impacts because their livelihoods depend on them (Andronov et al. 2021; Lavrillier and Gabyshev 2021).

A definitive analysis of Russia's climate and its dynamics based on instrumental observations showed that 2020 was the warmest year on record and the annual temperature anomaly from the climatic norm for 1961-1990 reached $+3.22^{\circ} \mathrm{C}$, which is more than 1 degree higher than the previous maximum in 2007 (Report on climate features on the territory of the Russian Federation, $2020^{6}$ ). For Russia as a whole, the warming rate for $1976-2020$ is $0.51{ }^{\circ} \mathrm{C}$ per 10 years. The winter of $2019 / 20$ was the warmest since 1936 and winter temperature anomalies in Western and Middle Siberia reached up to $+8.5^{\circ} \mathrm{C}$. Western and Eastern Siberia saw the largest annual air temperature anomalies in $2020,5.9$ and $4.7^{\circ} \mathrm{C}$, respectively. Annual precipitation grew in central Siberia by $3.3 \%$ per 10 years and in Eastern Siberia by $3.0 \%$ per 10 years.

Since the meteorological station network is rather sparse in Siberia, the use of modern Reanalysis data to estimate climatic characteristics is an important additional tool (Appendix S1). Based on the ERA5 Reanalysis and the CORDEX data, respectively (Gordov et al. 2018), the growing season length during 1979-2018 has varied between a decrease of 2 days per 10 years in a few locations to an increase of up to 8 days per 10 years over most of the area. The modelled trend of winter air temperature for 2015-2100 (using CMIP6 data) reaches $1.2^{\circ} \mathrm{C}$ per 10 years with pronounced latitudinal variability: $1.2^{\circ} \mathrm{C}$ per 10 years in the north to $0.4{ }^{\circ} \mathrm{C}$ per 10 years in the south.

\footnotetext{
5 https://climate.amap.no/

${ }^{6}$ http://www.meteorf.ru/upload/pdf_download/doklad_klimat2020.pdf
}

\section{EXTREME WEATHER}

People tend to observe extreme weather (Fig. 4), because of hazardous impacts (Rakhmanova et al. 2021), more than long-term climate trends. Since warming means that the atmosphere has more energy than previously, warming leads to an increase in frequency and magnitude of various extreme weather events (Table1) dissipating this excess energy. These weather events have increased since the mid1990s in Western Siberia causing significant damage to the economy and people (Evseeva and Romashova 2011; Aleseev et al. 2014; Kharyutkina et al. 2019; Appendix S1). Emergencies resulting from the development of deep mesoscale convection, such as thunderstorms, hail, squalls, and tornados, have been more frequent than before 2000 , and increased convective atmospheric instability has been recorded (Gorbatenko et al. 2020). In addition, periods of abnormally cold and warm weather are increasing (Volkova et al. 2019).

Throughout the first six months of 2020, a large region of Siberia experienced higher than normal temperatures. ${ }^{7}$ Surface atmosphere temperatures were up to $10^{\circ} \mathrm{C}$ above average in May, and the weather station in the town of Verkhoyansk $\left(67^{\circ} 33^{\prime} \mathrm{N}, 133^{\circ} 23^{\prime} \mathrm{E}\right)$ measured a maximum air temperature of more than $38^{\circ} \mathrm{C}$ on 20th June 2020, which is a new record temperature north of the Arctic Circle (Overland and Wang 2021; Fig. 4 a). In summer 2021, ground temperatures (usually higher than air temperatures) reached over $48^{\circ} \mathrm{C}$ in the same area; another new record. ${ }^{8}$ Such high ground temperatures accelerate permafrost thaw (see below) and dry the surface making it more combustible. High temperatures have resulted in earlier seasonal forest fires and a greater area of fires (Kharuk et al. 2021) with a record burn in summer 2021. Since the beginning of this season, more than 1300 forest fires have been registered in Yakutia, and the area covered by fire has exceeded 4.2 million hectares (Fig. 4b). ${ }^{9}$ Smoke plumes extended over $3000 \mathrm{~km}$ and as far as the North Pole, releasing record emissions of 505 megatonnes of carbon dioxide equivalent. ${ }^{10}$ Record temperatures are probably the reason for a new northern record set by a tundra fire on the Taimyr Peninsula. Lightning strikes that have increased three-fold north of 650 latitude (Holzworth et al. 2021; Fig. 4c) further increase the risk of forest (Kharuk et al. 2021) and tundra fires.

\footnotetext{
7 https://public.wmo.int/en/media/news/reported-new-record-temperatureof-38\%C2\%B0c-north-of-arctic-circle

${ }^{8}$ https://www.copernicus.eu/en/media/image-day-gallery/land-surfacetemperature-sakha-republic

${ }^{9}$ https://ria.ru/20210806/pozhar-1744617160.html

${ }^{10}$ https://modis.gsfc.nasa.gov/gallery/individual.php?db_date=202108-07
} 


\section{(a) Record heat wave}

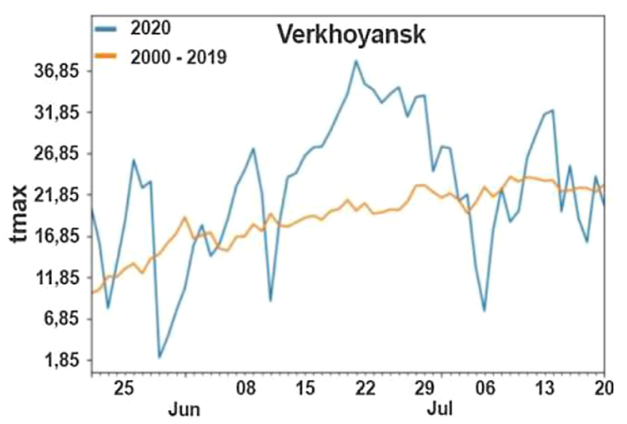

(c) Record lightning strikes

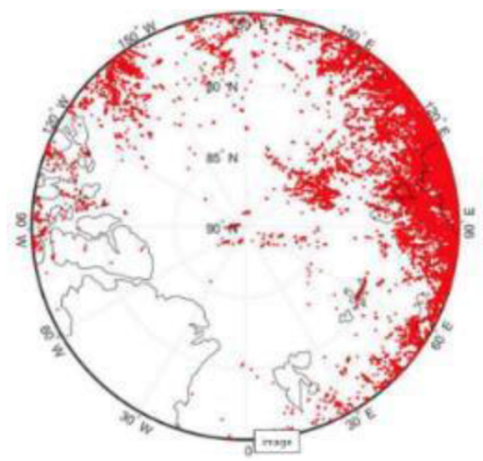

(e) recent torrential rain in the steppes

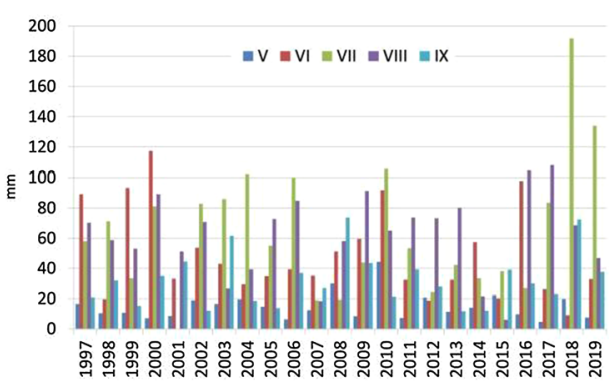

(b) Record Forest fires

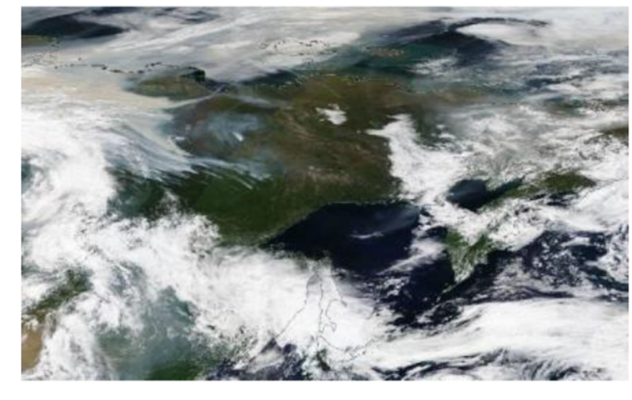

(d) record floods

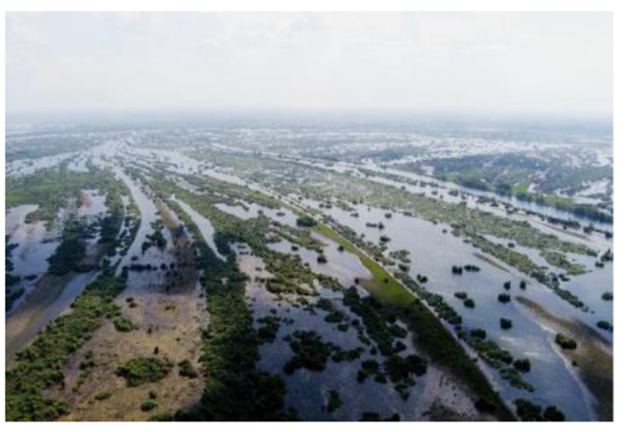

(f) more frequent rain-on-snow events

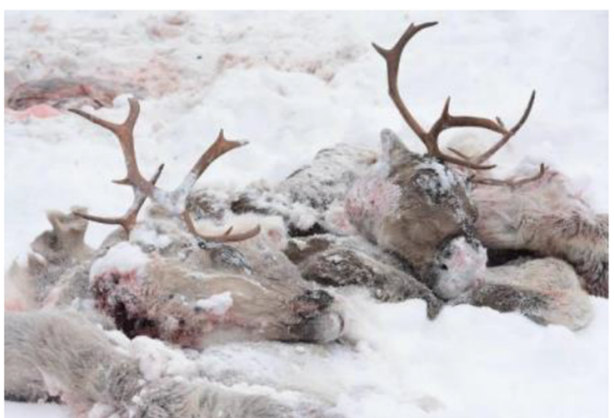

Fig. 4 Examples of extreme environmental events in Siberia. a record temperatures north of the Arctic Circle: Vekhoyansk 2020; b smoke plumes from record fires in the Yakutsk region, 2021 (Sakhalin is centre bottom, and the New Siberian Islands, centre top; c lightning strikes above $75^{\circ}$ N, June-August 2010-2020; d Ob-river flood near Krivosheino, 2021; e record rain in the arid Tuva region during July (month VII) 2018 and 2019; f increased and more intense rain-on-snow events kill tens of thousands of reinder. Credits: (a) modified from J. Day, euinteract.org; (b) A. Romanov; (c) Holzworth et al. 2021; (d) A. Kuznetsov; (e) unpublished data from Chadan meteostation, I.V. Kuzhevskaia; (f) M. Okotetto

Strengthening of the meridional transport of air masses is leading to record floods (Fig. 4d). The 2021 springsummer flood in the Yenisei river basin was caused by torrential rains and simultaneous snow melting in the mountains. The inflow of water was the largest on the Yenisei for the entire observation period since 1903. According to the estimates of the Russian Hydrometeorological Center, floods of this magnitude occur less frequently than once every 100 years. ${ }^{11}$

\footnotetext{
11 http://www.rushydro.ru/polovodie/news/?id=113854
}

\section{ARIDITY}

Drylands, which are defined as regions in which the aridity index (ratio of the annual potential evapotranspiration to annual precipitation) is less than 0.65 have expanded over the 60 years previous to the study by Feng and Fu (2013), and this expansion is projected to accelerate in the current arid regions of Siberia in the south (Greve and Seneviratne 2015). A projected increases of the aridity index in centraleastern Siberia will be caused mainly by precipitation deficit, while in Western Siberia, the potential 
evapotranspiration will exert greater effects (Zhou et al. 2020). Using the Ped index (Appendix S1), which is a normalised indicator of the ratio of air temperature to precipitation, Ryazanova and Voropay (2017) found that the mountain regions of the southern part of East Siberia have become more arid each month during the last 30 years. In the south of Western Siberia, aridity has increased in May and decreased in June. The increase in aridity is associated with both the increasing temperature and decreasing precipitation. Conversely, in the areas where an increase in precipitation and a decrease in average monthly temperature have been observed, some excessive moisture has been observed.

Superimposed on the complex climatic cause of changes in moisture is the possibility of increased soil moisture through permafrost thaw in some areas (Kirpotin et al. 2021a). Due to a weakening of the Atlantic transfer of air masses and an increase in the meridional transfer, cold humid air from the Arctic is moving south along the meridian and colliding with the over-heated Mongolian anticyclone (Mokhov et al. 2013). In this collision zone of the fronts (Kozlov et al. 2019; Akperov et al., 2021), hurricane winds and torrential precipitation have been recently observed (Fig. 4e), and this has led to the steppes and sands turning "green" in some areas of Mongolia, Khakassia, and Tuva (Kirpotin et al. 2021a).

\section{DIVERSE CRYOSPHERE CHANGES}

Changes in temperature and precipitation affect the elements of the diverse cryosphere which abound in Siberia: glaciers, permafrost, sea, and lake and river ice, and snow (Table 1).

\section{Glaciers}

During the Last Glacial Maximum ( 24-18 ka), ice sheets covered large parts of the Northern Hemisphere's continents while Siberia-even its northeastern part-remained largely ice free (Bakker et al. 2020). More recently, until the middle of the 1970s, Eurasian glaciers were in a quasistationary state in most of the mountain areas of the region Khromova et al. 2014). Now, the glaciers are degrading in all the mountain areas of Eurasia: small glaciers are disappearing, the termini are retreating, the area and volume of glaciers are decreasing, their surfaces are covered with moraines, and large areas of dead ice are being formed. Also, compound glaciers are broken into simpler components.

In Siberia, there are several glacial areas including the Altai Mountains located at the junction of Russia, Kazakhstan, Mongolia, and China (Volkov et al. 2021). The
Siberian Altai Mountains cover about $70 \%$ of the area of all south Siberian glaciers, which provide fresh water to the upper tributaries of the $\mathrm{Ob}$ and Yenisey rivers. Summer warming combined with precipitation changes (at some altitudes) has decreased the total glacier area in the Aktru river basin in the central Altai mountains by $7.2 \%$ (1.2 $\mathrm{km}^{2}$ ) from 1952 to 2006 (Surazakov et al. 2007; Narozhniy and Zemtsov 2011). During the last 30 years, decadal loss rate of the Aktru basin glaciers nearly doubled, with the area of loss accelerating from $0.9 \%$ to $1.6 \%$ per decade. The Altai glacier's rate of retreat reached $1.35 \%$ per year in 2002-2009 and glaciers retreated 2-3 times faster in 1994-2009 than during 1957-2009. However, the areas of large glaciers have stabilised since 2005 due to increased precipitation (Adamenko et al. 2017). With a 59\% loss of area, since the end of the Little Ice Age (Osipov and Osipova 2015), deglaciation in the southeastern Siberian mountains during the second half of the twentieth century was more intensive than in northeastern Siberia and the Altai Mountains. Retreat of glaciers opens up new land for colonisation by vegetation and ecological succession leading to ecosystems of greater complexity (Volkov et al. 2021).

\section{Permafrost}

Permafrost is ground substances (soil, peat, rock etc.) that remain below $0{ }^{\circ} \mathrm{C}$ for more than two years. It occupies $22.8 \times 10^{6} \mathrm{~km}^{2}$ in the Northern Hemisphere and about $10.4 \times 10^{6} \mathrm{~km}^{2}$ in Russia (Gruber 2012) where it shows all the distribution patterns from continuous, through discontinuous and sporadic to isolated patches (Anisimov and Zimov 2021). In Siberia, permafrost landscapes are diverse (Fig. 5). They stretch from the Arctic islands and continental shelves in the Arctic to the mountains of the south and beyond into Mongolia. Permafrost zones in Western Siberia follow the above order of distributional patterns from north (continuous) to south (sporadic) until the southern Siberian latitudes where permafrost is absent. However, in the mountainous regions to the east, and particularly on the borders with Mongolia, all types of permafrost distribution are found locally (Zheleznyak et al. 2020).

Permafrost is sensitive to ground warming and insulation by snow and vegetation, particularly mosses (Anisimov and Zinov 2021; Kharuk et al. 2021). It is also sensitive to the massive forest fires currently characteristic of Siberia (Kharuk et al. 2021). In the past decade, permafrost has warmed throughout the Arctic by about 0.2 to $0.4{ }^{\circ} \mathrm{C}$ (Biskaborn et al. 2019) with some isolated patches disappearing in northernmost Sweden (Åkerman and Johansson 2008). 
Thawing permafrost in Siberia has many impacts including changing landforms and hydrology, destabilising surfaces leading to infrastructure damage, releasing ancient carbon via greenhouse gases (Anisimov and Zimov 2021) and releasing archaeological artefacts formerly preserved in frozen peat. Thawing permafrost also releases microorganisms, some of which are harmful and others about which little is known (Legendre et al. 2014; Shmakova et al. 2021), and it also affects other types of biodiversity such as that of rare mountain mires (Volkova et al. 2021). Permafrost is used by local people to store food (Andronov et al. 2021), and thaw could affect this traditional food storage system. However, perhaps of greatest concern is the release of greenhouse gases (Schuur et al. 2015; Walter Anthony et al. 2018; Christensen et al. 2019), particularly the potent greenhouse gas methane from the great wetlands of Western Siberia (Kirpotin et al. 2021b; Tsyganov et al. 2021; Minayeva et al. 2021). These emissions could potentially add to global warming although not as dramatically as estimated earlier (Anisimov and Zimov 2021). In contrast, warming-driven "greening" of vegetation, for example in expanding glacial forefields (Volkov et al. 2021) and ascending treelines (Kharuk et al. 2021; Rees et al. 2020; Volkov et al. 2021), are expected to partly offset loss of carbon from thawing permafrost soils (Pascual et al. 2021).

Changes in landscapes through permafrost thaw can be dramatic and fast (Fig. 5). Islands in the Laptev Sea have disappeared (Klyuyev et al. 2008), polygonisation (Fig. 5a) has occurred in some areas of Taimyr in less than 12 years (Matveyeva and Zanokha 2013), a thawing palsa plateau in The Altai Republic is being colonised by trees (Fig. 5b), and baidgerakh erosion has revealed the Pleistocene landscape level on the New Siberian Islands (Figs. 5 a,b; Callaghan pers. obs.). Hollows have been created by explosions of other types of mounds in the Yamal and Gydan areas leaving large craters (Leibman et al. 2014; Buldovicz et al. 2018; Bogoyavlensky et al. 2021). The first crater described in 2014 had $18 \mathrm{~m}$ inner diameter, $30 \mathrm{~m}$ outer diameter, and $70 \mathrm{~m}$ depth (Leibman et al. 2014) (Fig. 5e); Elsewhere (the Yamal and Gydansky Peninsulas, Taimyr, and Yakutia) anthropogenic activity has triggered thawing leading to the formation of huge thaw slumps (Figs. $5 \mathrm{f}$ and 6; Savvinov et al. 2018).

\section{Ice}

Loss of sea ice leads to Arctic amplification of temperature increase and increased coastal storms that affect the land (Forbes et al. 2016). Loss of coastal sea ice has led to the opportunity of increased transport possibilities with resulting development of infrastructure on land such as the recently built Sabetta LNG plant on the Yamal Peninsula. ${ }^{12}$ Sadly, increased access also has led to increased militarisation. ${ }^{13}$

Transport infrastructure in Western Siberia and elsewhere is strongly influenced by major rivers such as the Ob, Pur, and Tom (Rakhmanova et al. 2021) and lakes. The dynamics of rivers and lakes is an important source of uncertainty in terms of timing of floods and availability of ice roads and fish. As temperatures are increasing, the duration of lake and river ice is decreasing. The opening and clearing of the rivers of the Siberian and Eurasian parts of Russia took place 4-27 days earlier in 2020 than during the average long-term period 1990-2020): as early as March rather than the second half of May (Report on climate features on the territory of the Russian Federation 2020). Also, river-ice formation in most of Russia occurred later than normal in the fall of 2020 . The appearance of ice on the rivers of Eastern Siberia in the fall of 2020 began 2-28 days later than the norm (Report on climate features on the territory of the Russian Federation 2020).

Icing blisters are very important for the Evenki herders and hunters of Eastern Siberia as they are interrelated with good grazing areas for domestic reindeer. These understudied phenomena (up to $7 \mathrm{~m}$ thick mounds of ice on rivers) explode when trapped gases from below force their way out. These icing blisters have declined since 2014 (Lavrillier and Gabychev 2021).

\section{Snow}

Snow cover is an important climatic characteristic determining the region's surface energy budget, ground thermal regime, and freshwater budget. It is characterised by the areal snow cover extent (SCE), the snow cover duration (SCD), which is the time period of continuous snow cover in between snow-on and snow-off dates, and the amount of accumulated snow described either by snow depth (SD) or snow water equivalent (SWE), which is the depth of water stored by the snowpack. These characteristics depend on temperature and cold season precipitation regimes and vary throughout Siberia mainly according to meridional and altitudinal gradients.

There is inherent regional variability of snow characteristics throughout the vast and diverse regions of Siberia. Regionally, mean annual SCDs increase with latitude, the longest being more than 270 days along the Arctic coast (Zhong et al. 2021). Changes in snow characteristics across this regional complexity showed no single strongly

\footnotetext{
$\overline{12}$ https://www.hydrocarbons-technology.com/projects/yamal-lngproject-russia/

13 https://www.volterrafietta.com/the-russian-federation-creates-a-newbase-in-the-arctic
} 
(a)

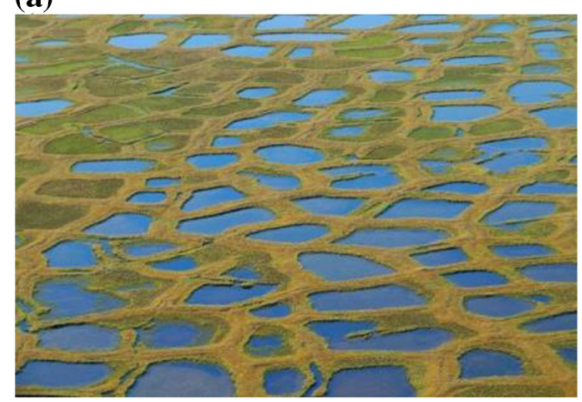

(c)

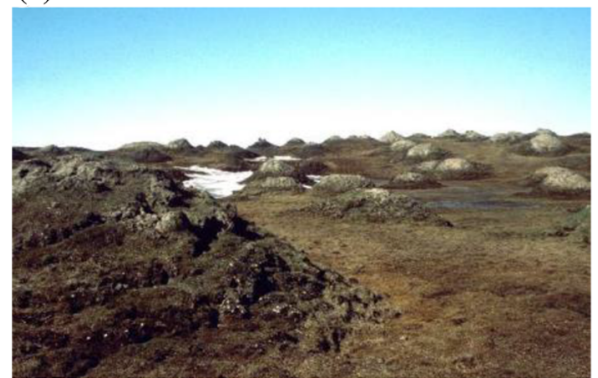

(e)

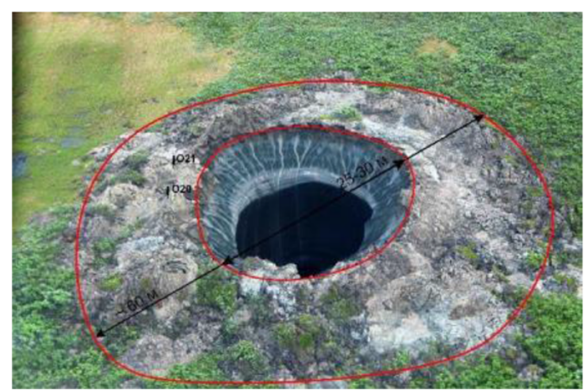

(b)

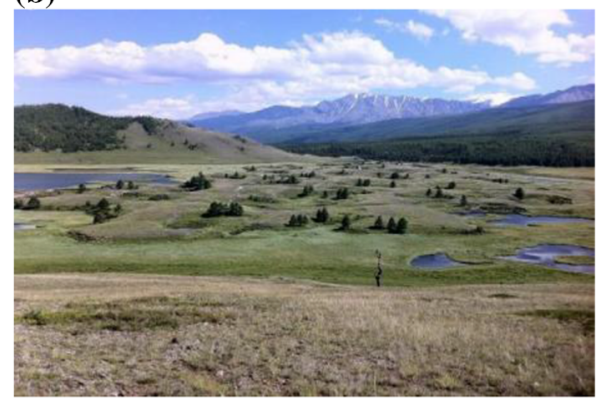

(d)

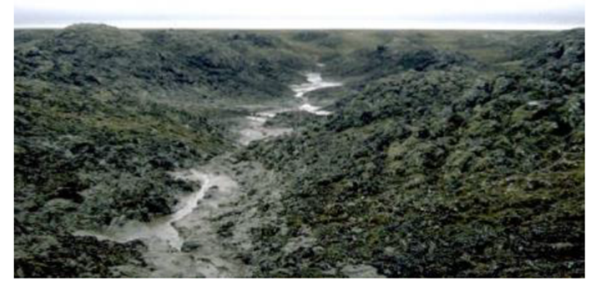

(f)

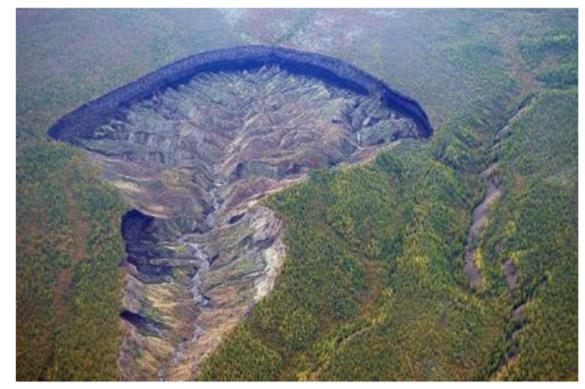

Fig. 5 Diversity of permafrost landscapes in Siberia showing effects of thaw. a Low-centred polygonal tundra along the coast of Yakutia-Sakha near Samoylov; b Thawing palsa plateau: Altai Republic; c The baidzharakh landscape, Ostrov Faddeyevsky Island; d Permafrost thaw and eroding baidzharakhs, Ostrov Faddeyevsky Island; e Crater and mound in Yamal, $18 \mathrm{~m}$ inner, and $30 \mathrm{~m}$ outer diameter, and $70 \mathrm{~m}$ deep, caused by a natural explosion in a permafrost area; f The Batagay thermokarst mega-thaw slump, in 2018 the width was $>800 \mathrm{~m}$, length $>2,500 \mathrm{~m}$, depth $<100$ m. Photo credits: (a) K. Piele; (b-d) T.V. Callaghan; (e) M. Leibman; (f) A. Gabysev

pronounced tendency from 1966 to 2010 under ongoing climate change (Bulygina et al. 2011) which is consistent with findings by Pulliainen, et al. (2020) who found that although a trend of decrease in snow water equivalent is strongly pronounced in the Northern Hemisphere, it is negligible across Eurasia. However, a recent assessment in Russia found that the trend of decreasing snow cover duration persists from 1976 to 2020 in a large part of Russia and the maximum winter snow depth continues to increase in most of the country (Report on climate features on the territory of the Russian Federation 2020).

Significant trends of snow characteristics have been found in various regions within Siberia. Thus, the sum of precipitation in November to April (mainly as snow) has increased in most of Siberia, and by up to $30 \mathrm{~mm}$ in 10 years (Anisimov and Zimov 2021). The greatest increases have been in Western Siberia and the Far East.
Near the Cherskiy Research Station in the Kolyma Lowland, snow depth nearly doubled in recent years (Anisimov and Zimov 2021). However, during 1970 to 2013, dramatic reductions in the average areas of spring snow cover extent of Siberia occurred in spring from 6.6 to 5.5 million $\mathrm{km}^{2}$, which accounted for approximately $8.5 \%$ of the area of Siberia (Yu et al. 2017). The average spring snow cover area north of $60^{\circ} \mathrm{N}$ decreased in May and June by $-3.5 \%$ $( \pm 1.9 \%)$ and $-13.4 \%( \pm 5.4 \%)$ per decade respectively between 1967 and 2018 (relative to the 1981-2010 mean) (Meredith et al. 2019). Even though a delayed onset of snow cover was also found, there was surprisingly no significant overall long-term SCD trend. In contrast, Gorbatenko et al. (2019) found that in the southern part of Western Siberia, the duration of a steady snow cover has increased on average by 4 days (up to 10 days in the north) due to increased precipitation whereas in the northern art of 


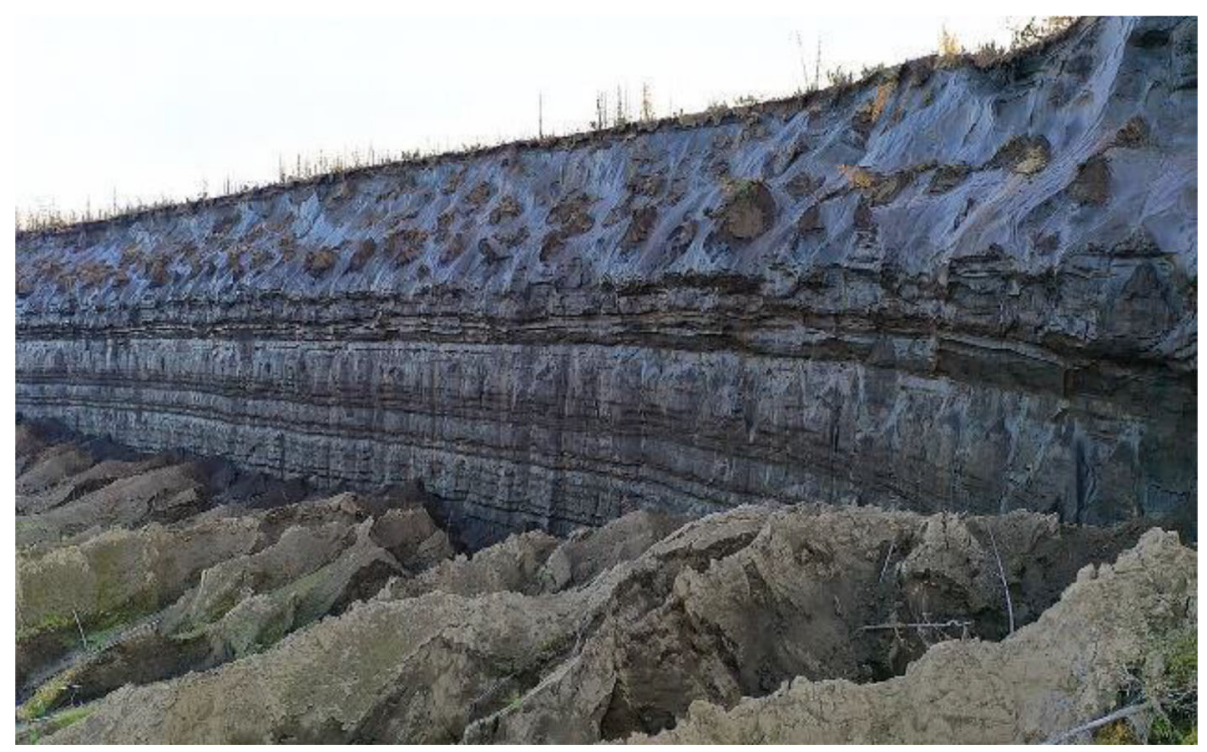

Fig. 6 Detail of the Batagay permafrost mega-thaw slump: the standing and fallen trees indicate scale. Photo: A. Desyatkin

Western Siberia, the period of snow cover has decreased by up to 2 weeks since 2000 (Titkova and Vinogradova 2017).

Snow cover interacts with vegetation and wind: there is a significant difference of snow accumulation in forest and fields of Siberia plains (Sosnovsky et al. 2018). During 1966-2010, in the south of Western Siberia, the maximal snow storage values averaged $125 \mathrm{~mm}$ in forests and $107 \mathrm{~mm}$ in fields while in the east of Siberia values averaged $64 \mathrm{~mm}$ and $70 \mathrm{~mm}$, respectively. After 2000, maximal snow storage in Western and Eastern Siberia decreased in forests by $7 \%$ but in fields it increased by $2 \%$, probably associated with decreases in wind speeds over $10 \mathrm{~m} / \mathrm{s}$ (Rakhmanova et al. 2021).

Snow cover influences albedo, permafrost, depth and timing of soil freezing, biogeochemical activity and habitats, and species, with consequences for ecosystem services. Snow surface state, like formation of ice crusts after rain-on-snow (ROS) events or after winter snow surface thawing and refreezing, impede animal foraging. On the Yamal Peninsula, autumn/winter ROS events have become more frequent and intense (Bartsch et al. 2010; Forbes et al. 2016). Two major ROS events (November 2006 and 2013) led to massive winter reindeer mortality episodes-the starvation of 61000 reindeer out of a population of ca. 275 000 animals during autumn/winter 2013-2014 (Fig. 4f) and invasion of scavengers from the south into the Yamal area (Sokolov et al. 2016). Such changes are crucial for the futures of northern Indigenous populations.

\section{BIODIVERSITY}

Loss of global biodiversity is a major concern and one of the key sustainability goals of the UN (Jensen 2021). The great diversity of Siberian landscapes and climates has resulted in a large biodiversity (Table 1) with globally important endemic species in remote areas such as the Altai and Tyva Republics (Pyak et al. 2008) and many red-list species (Vaganov et al. 2021). Within Russia, there is a great expertise in taxonomy and systematics. While many researchers are developing methods to classify bryophytes into functional groups for studying ecosystem-level processes because of difficulty of identification in the field (Lett et al. 2021, Siberian researchers focus on detailed species-level identifications (e.g. Volkova et al. 2021) which adds to the understanding of baseline biodiversity and current dynamics. However, many remote and inaccessible regions exist in Siberia and these are under-studied. Consequently, new species and even genera are still being discovered (Vaganov et al. 2021). Also under-studied is the ancient biodiversity of organisms preserved-and viable-in permafrost. Organisms can survive in permafrost for more than 8000 years (Panikov et al. 2006; Jansson and Taş 2014), but it is not known if these organisms are beneficial or harmful (Waits et al. 2018). Anthrax pathogens have emerged in Yakutia (Revich and Podolnaya 2011) and unfortunately have killed people in 
the Yamal-Nenets Autonomous Okrug (Popova et al. 2016; The Barents Observer ${ }^{14}$ ).

Biodiversity is changing throughout Siberia (Kharuk et al. 2021; Kirpotin et al. 2021a; Volkov et al. 2021; Volkova et al. 2021) in response to various drivers, including climate change, land use, and release of land by glacier retreat. Simplistically, space-for-time analogues suggest that tundra would become taiga, taiga would become steppes, and steppes would become semi-desert (Fig. 1), but the reality is far more complex.

Kirpotin et al. (2021a) show that some species formerly locally extirpated by hunting are now returning; insect forest pests are moving north, consistent with warming; mammals such as the racoon dog are spreading eastwards facilitated by the Trans-Siberian Railway; bird distributions are changing in latitude and mountain altitude and are affected by trapping outside Russia; Taimyr reindeer populations are decreasing through lack of control of wolf predator populations, over-culling, and poaching; native fish populations are declining because of introductions of alien fish; and amphibians are predicted to move northwards.

Specific elements of biodiversity in remote and inaccessible regions, such as mountain mires and their bryophytes, are understudied and potentially particularly vulnerable to environmental changes-both climate and land-use (Volkova et al. 2021). In contrast, melting glaciers are releasing new land for colonisation by microbes, plants, and invertebrates (Volkov et al. 2021). In the Siberian tundra, vegetation change should be greater than elsewhere because of amplification of Arctic warming. "Greening" (plants growing more, becoming denser, and shrubs encroaching on typical tundra grasses and mosses) is indicated by satellite observations from Landsat (Berner et al. 2020) but greening is not uniform. Also, remotely sensed estimations of NDVI (the Normalised Vegetation Index), the proxy that represents "greenness", do not always agree with ground measurements (Myers-Smith et al. 2020) although ground measurements in Siberia are few (Callaghan et al. 2021a). Some studies, for example in Taimyr, show stability of vegetation change despite rapid and significant landscape transformations (Matveyeva and Zanokha 2013). NDVI changes depended on local temperature gradients, local precipitation, surface wetness, changes in the length of the snow-free period, and growing season length (Frost et al. 2014, 2018). They also reflect tree species migrating northward (MacDonald et al. 2008; Rees et al. 2020; Kharuk et al. 2021) and into some areas of

\footnotetext{
14 https://thebarentsobserver.com/en/arctic/2016/08/scientist-yamalanthrax-outbreak-could-just-be-beginning
}

the steppes (Kirpotin et al. 2021a). In contrast to greening, northern forests are "browning" as fires increase in response to rising temperatures and increased electrical storms (Kharuk et al. 2021).

\section{LOCAL SOCIETAL CONSEQUENCES OF CHANGE}

Climate change in concert with anthropogenic activities such as urban and access development, and resource extraction, have the potential to impact traditional life styles landscapes and biodiversity—and even feedbacks to climate.

Changes in biodiversity and ecosystems affect the way ecosystem services can be available and how competition for services may change among stakeholders (Minayeva et al. 2021). Changes in ecosystem services together with regulations and globalisation affect traditional food sources that in turn affect the health of Indigenous Peoples (Andronov et al. 2021). However, the perceptions of environmental changes and their impacts vary according to locations where people live and their education and life styles (Rakhmanova et al. 2021). Perceptions need to be correct-or science needs to be made more relevant-in order for people to mitigate and/or adapt to changes in order to build sustainable futures. As Russia has more Arctic cities and city dwellers than any other Arctic country, building sustainable cities is very important as well as translating health care infrastructure into increased survival and longevity (Orrtung et al. 2021).

Throughout history and prehistory, people of Siberia have experienced environmental change. Over the past 10 000 years, naturally occurring warm, cold and wet periods have resulted in changes in glaciers, forests, treeline, and peatlands (Groisman et al. 2013; Tsyganov et al. 2021). Over the past 300 years, migrations of people from the west have resulted in the exploitation of natural resources, deforestation, extermination of some species, and expansion of agriculture. Indigenous People have adapted to the new conditions and experienced modern globalisation; some have become integrated in urban communities while other ethnic groups, e.g. nomads, follow traditional life styles (Abramov 2017; Pilyasov and Kibenko 2020; Lavrillier and Gabychev 2021; Andronov et al. 2021). Within the past 30 years, climate change and direct human activities, e.g. from "shift workers" temporarily relocating to service increasing industrial activities (Loginov et al. 2020), have had large local, impacts such as the growth of cities, increase in pollution, increased permafrost thaw, increases in forest fires and changes in species distributions. In contrast, increased conservation measures have enabled some species to re-establish and abandonment of agricultural land and villages (e.g. in the Krivosheinskiy 
District of the Tomsk region ${ }^{15}$ has led to secondary succession and reversion to natural ecosystems. Such societal changes have led to increased competition by various stakeholders for access to non-compatible ecosystem services (such as reindeer herding and extractive industries), and conflict resolution is becoming a necessity (Minayeva et al. 2021).

Interacting with the multiple "natural" environmental changes is changes in industrial activity, regulations, the economy, and human behaviour. Examples are pollution events such as oil spills and emissions of noxious fumes from industrial processes (Fig. 7), changes in diet of Indigenous People that affects their health negatively (Andronov et al. 2021), different perceptions of climate change that affect how people respond to mitigating its effects (Rakhmanova et al. 2021), insufficient enforcement of regulations of protected areas (Kirpotin et al. 2021a), and particularly forests (Kharuk et al. 2021), and introductions of alien fish species (Kirpotin et al. 2021a, b).

\section{GLOBAL SOCIETAL CONSEQUENCES OF CHANGE}

Siberia has global importance for its feedbacks to the climate system. These include Siberian seas that are losing sea ice (Mallett et al. 2021) leading to ocean warming and increased storms - and even impacts on mid-latitude weather. The feedbacks also include methane emissions from the continental shelves (Kosmach et al. 2015) and from permafrost, particularly in Western Siberia (Anisimov and Zimov 2021). The great rivers of Siberia transport carbon to the Arctic Ocean, although most emissions are released before transport (Serikova et al. 2018; Karlsson et al. 2021).

The vast wetlands such as the Great Vasyugan Mire (Kirpotin et al. 2021b) and extensive forests (Kharuk et al. 2021) sequester the greenhouse gas carbon dioxide while extensive areas of vegetation on permafrost have sequestered and stored carbon for millennia (Tsyganov et al. 2021). Carbon storage is an important ecosystem service (Minayeva et al. 2021). Current warming of carbon-rich permafrost soils, drainage of peatlands, and deforestation (through increased fires and logging) are reducing both storage capacity and increasing greenhouse emissions-a "double whammy". Although observations of carbon storage are relatively many (e.g. Pascual et al. 2021), and there are measurements and models of carbon emissions (e.g. Anisimov and Zimov 2021), the land area of Siberia is not adequately covered by essential studies such as those determining greening, browning and stability of vegetation

$\overline{15}$ http://kradm.tomsk.ru/
(Callaghan et al. 2021a) while observations for remote areas such as the southern mountains are rare (Volkova et al. 2021). Although local emissions of methane can be high overall, models suggest that the previously predicted "methane bomb" resulting from warming permafrost will be smaller than expected but nonetheless significant, particularly from the great wetlands of Western Siberia (Anisimov and Zimov 2021). Short-term events such as forest and tundra fires, insect pest outbreaks, and death of tundra vegetation following winter warming events (Bokhorst et al. 2009; Kharuk et al. 2021) release significant amounts of carbon in the short term.

Other feedbacks from the Siberian land surface include albedo, i.e. the reflectivity of the surface. Loss of glacier area, advance of tall shrubs into the tundra (Myers-Smith et al. 2015) and northward and upward movement of the treeline (Gatti et. al. 2019; Rees et al. 2020; Kharuk et al. 2021; Volkov et al. 2021) reduce albedo leading to warming. The decreasing period of snow cover in Western Siberia by up to 2 weeks since 2000, reduced periods of lake and pond ice, and black carbon on snow (emissions from industry and forest fires) also reduce albedo and increase heat absorption that, in turn, leads to greater carbon emissions.

Negative feedbacks can moderate, but not yet negate, such positive feedbacks. Negative feedbacks include increased carbon draw-down by faster-growing plants that reduces warming. Increased canopies that persist longer through the growing season can lead to warming through reduced albedo (Chapin et al. 2005) but experimental studies in Siberia (Blok et al. 2010) show that shrubs cool the ground surface and protect permafrost. Increased evapotranspiration by thicker forest canopies cools the atmosphere, particularly in early summer (Göttel et al. 2008) and the ground surface by shading which can increase moss growth and promote shallower active layers (Kharuk et al. 2021).

Because of the vastness of Siberia, net positive feedbacks to warming are likely to have global impacts. As the processes of deforestation, fire control, and peatland conservation are largely controllable by legislation and its enforcement, Siberia can either exacerbate or mitigate climate warming with impacts far beyond its borders.

\section{WAYS FORWARD}

\section{Improving dialogue among stakeholders}

A conference in Salekhard (Yamalo-Nenets Autonomous Region) bringing together researchers, Indigenous Peoples, and decision makers made recommendations for improving 


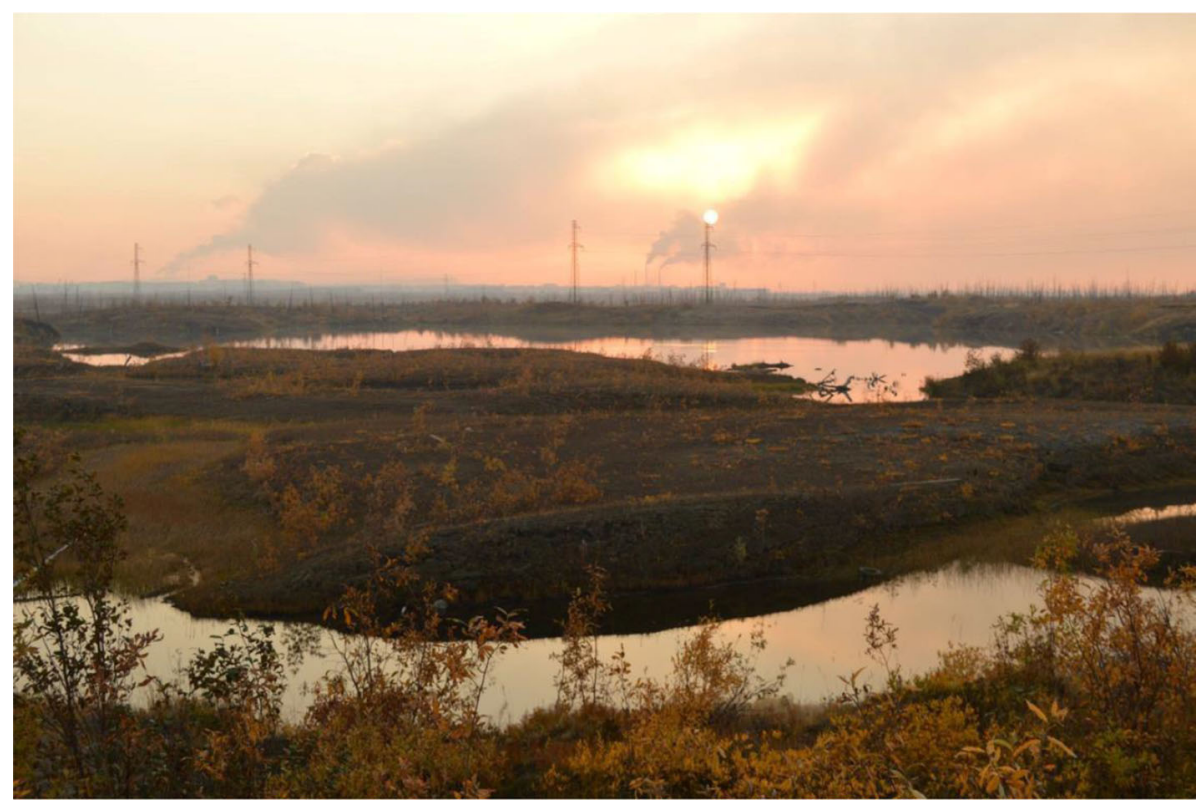

Fig. 7 Dead forest and vegetation, near Norilsk. Photo: S.N. Kirpotin

dialogue among these different groups (Callaghan et al. 2020b).

The current Special Issue studies have acted on many of these recommendations. Among them are the following:

- "Developing guidelines for research stations to improve interactions with local communities". This has been interpreted here as improved outreach from science, combining different ways of knowing, and understanding and responding to different perceptions of change (Rakhmanova et al. 2021).

- "Recognising and using multiple "ways of knowing"". This recommendation specifically highlighted "the power of combining science observations with the knowledge and observing capacity of Indigenous and local peoples". We present several "ways of knowing" including Indigenous Knowledge (Lavrillier and Gabychev 2021).

- "Improving the impact of research by making science agendas and findings available in a variety of formats and languages", "Ensuring communication at multiple geographic levels" and "Improving communication at all levels of society". SecNet, working closely with INTERACT, has produced an outreach book (e.g. Callaghan et al. 2020c, 2021c), videos, computer animations, webinars and media appearances that together represent the "variety of formats". These communications and their diverse formats use or underpin many of the studies in the Special Issue. The outreach materials are available to the general public, school, and university students through many platforms including the University of the Arctic. ${ }^{16}$ All are freely available online, and they have been particularly important during the COVID-19 pandemic. However, people need to "know" in their own languages and translation into multiple languages remains an expensive challenge.

Recommendations that remain to be implemented are:

- "Consulting widely when constructing research agendas to ensure the research is relevant, encompasses all sectors, knowledge types, disciplines and is sustainable to its conclusion". Although the Special Issue as a whole adheres to this principle, each study is tightly constrained by specific approaches. To implement the recommendation at the level of future such studies, it is necessary to develop outreach to local populations tuned to their specific perceptions and to develop partnerships among the owners of different knowledge types.

- "Ensuring that the three groups [Indigenous Peoples, Researchers and Decision Makers] work together to review the effectiveness of existing legislature ad possible requirements for new laws relating to conflict in land use from environmental change". Studies within the Special Issue have reinforced this recommendation by highlighting the need for ecosystem services conflict resolution (Minayeva et al. 2021) and the need to review regulations. These include fishing quotas and fish introductions and inappropriate Taimyr reindeer

\footnotetext{
${ }^{16}$ https://www.uarctic.org/
} 


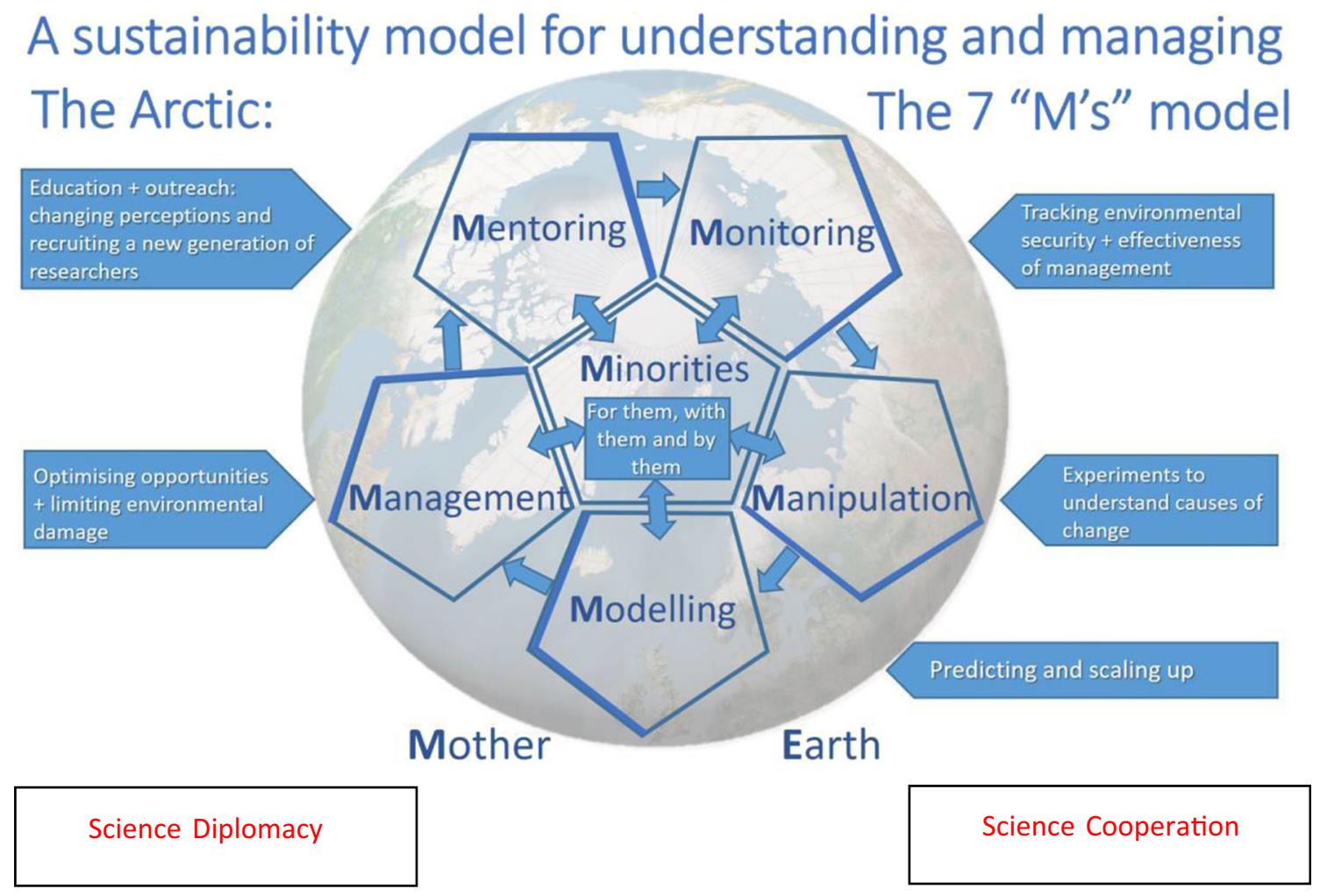

Fig. 8 The "7 M's" method for sustainable environmental research and management

quotas on one hand (Kirpotin et al. 2021a) and, on the other hand, well-intentioned but problematic legislation of natural food sales at inappropriately equipped places (e.g. from sledges (Andronov et al. 2021). We would add to this recommendation the urgent need for enforcing existing relevant legislature such as that combatting illegal deforestation. Implementation of this recommendation needs careful dialogue among all sectors followed by action.

New recommendations have been made explicitly in this special issue on Siberian environmental change. We recommend:

- Use of ecosystem service models for land-use optimisation including resolution of conflicts among opposing land uses.

- Updating of conservation regulations, for example related to hunting and fishing, and better enforcement of existing relevant regulations to protect forests and natural parks, particularly by reducing poaching, illegal logging as well as illegal building.

- Wider implementation of conservation to ensure that some unique areas (e.g. the Great Vasyugan Mire and other Siberian wetlands) are conserved not only for the local benefit of ecosystem services but for contributions to global protection of biodiversity and carbon drawdown and storage.
- We also recommend a model approach for ensuring sustainable environmental research and management by integrating the various components (Fig. 8).

\section{Implementing a sustainable model for assessing and responding to environmental change}

The scale of environmental change and the magnitude and diversity of its impacts (and opportunities) are so great that multiple actors are needed to work together to ensure satisfactorory and long-term, sustainable outcomes. However, it is a challenge to initiate and maintain appropriate dialogue among Scientists, Decision Makers, and Indigenous Peoples (Callaghan et al. 2020b): too often, management is not science based (Callaghan and Shaduyko 2020). Furthermore, even within the science community, connections between disciplines and research and monitoring approaches can be poor. An attempt to improve this situation has been made by the Arctic Council that encourages science cooperation. ${ }^{17}$ However, science cooperation cannot have societal relevance unless connections are made with residents and decision makers. Consequently, we propose a scheme (the "7 M's Approach") to improve interactions

\footnotetext{
${ }^{17}$ www.arctic-council.org
} 
among all actors (Fig. 8). This is an extension of the " 3 Ms" approach described by Johansson et al. (2012).

The starting point of the scheme is environmental Monitoring that tracks environmental changes as they are happening over time. Many observation and monitoring activities and organisations exist such as $\mathrm{SAON},{ }^{18}$ AMAP $^{19}$, and INTERACT ${ }^{20}$ and many of the papers in this Special Issue present invaluable information on monitoring (e.g. Lavrillier and Gabyshev 2021; Kharuk et al. 2021; Kirpotin et al. 2021a). However, monitoring does not necessarily reveal information on infrequent and sudden extreme events or thresholds for sudden and dramatic environmental and ecosystem changes to occur. Furthermore, when environmental damage is recorded, it is too late to act: we need to be forewarned.

Manipulation activities seek to change environmental and ecosystem components in a controlled way in the field to understand causes and consequences of change (De Boeck et al. 2015). Manipulations can be at a large spatial scale and ensure ecosystem integrity whereas studies from laboratory experiments can be regulated more precisely and responses measured in greater detail albeit in artificial conditions (e.g. soil microcosms and ecotrons). Field experiments can explore impacts in the field of specific changes such as air and soil warming, atmospheric $\mathrm{CO}_{2}$ concentrations, UV-B radiation fluxes, changes in snow depth and duration, changes in soil nutrients, etc. beyond what is currently experienced during monitoring. In addition, manipulation experiments can be used specifically to explore environmental threshold exceedance and extreme weather events (Preece et al. 2012; Bokhorst et al. 2009). Networks of manipulation projects exist and include ITEX $^{21}$ and AnaEE. ${ }^{22}$ Although D.I. Berman (in Kirpotin et al. 2021a) uses laboratory experiments to test the tolerance of amphibians to low temperatures and anoxia, few studies in this Special Issue use the environmental manipulation approach and this is highly recommended for the future.

Another type of environmental manipulation is to change the evironment deliberately to remediate damaged ecosystems (e.g. flooding drained peatlands) or to sequester atmospheric $\mathrm{CO}_{2}$, e.g. by planting trees and flooding land as implemented, for example, by Heathrow Airport, UK. ${ }^{23}$ This type of manipulation starts as an experiment that can be refined as a management practice.

\footnotetext{
$\overline{18}$ https://www.arcticobserving.org/

19 https://www.amap.no/

20 https://eu-interact.org/

21 https://www.gvsu.edu/itex/

22 https://www.anaee.eu/

23 https://www.scotsman.com/business/heathrow-airport-invests-scottishcarbon-sinks-it-goes-carbon-neutral-1885841
}

Environmental manipulation experiments are demanding in terms of space and resources and are often limited to very few variables. There is, therefore, an essential need to combine information from monitoring and manipulation experiments to generalise results over wider areas and to predict into the future.

Modelling enables us to take our understanding from monitoring and manipulation to new and wider areas and into the future. IPCC models of climate change (Houghton et al. 1990) forewarned of climate warming and its impacts more than 30 years ago! Within this Special Issue, modelling has been used at different scales and with varying complexities from a population model that predicts the decline of the Taimyr reindeer population (Kirpotin et al. 2021a) to combined climate, permafrost, and greenhouse gas emission models that predict permafrost thaw and methane emissions of global relevance (Anisimov and Zimov 2021). Such models can inform Decision Makers about the implications of environmental change and provide scientific evidence to underpin timely mitigation and/ or adaptation responses.

Management, local and international, aims at mitigating unwanted impacts of environmental changes, adapting to those changes we cannot control, and exploiting any opportunities that arise. Within the $7 \mathrm{M}$ 's concept, it is explicit that Management should depend on science that is based on monitoring, manipulation, and modelling. Too often, however, conflicts between long-term environmental integrity and short-term economic gain for industry are resolved in favour of short-term gain (Callaghan and Shaduyko 2020). Thus, ecosystem services are usually dominated by extractive industries over sustainable ecosystem use by local stakeholders (e.g. Minayeva et al. 2021). Regulations - often well intentioned-need to be monitored to check their effectiveness. Well-intentioned hygienic native food sale regulations together with climate change are affecting the consumption of native foods with resulting health problems (Andronov et al. 2021) and although Russian Arctic cities have a higher number of hospital beds and doctors than Arctic cities in other Arctic countries, life expectancy is lower (Orttung et al. 2021).

Appropriate management regulations need suitable enforcement. For example, damage to forest ecosystems and biodiversity by illegal logging need to be significantly reduced. At the same time, novel management options should be explored to mitigate and adapt to climate change such as protecting and flooding formerly drained peatlands to enhance carbon draw-down and storage. This is particularly important in Siberia that contains the world's largest wetland (Kirpotin et al. 2021b).

Mentoring includes outreach to the public and education to inform and to equip the next generation of scientists with adequate skills and knowledge to use their future 
environment in a more sustainable way than previous generations have done. Appropriate opportunities should be made available to ensure a better dialogue among researchers, decision makers, and Indigenous and local people (i.e. "Minorities") from an early stage. Improved science cooperation pursued by the Arctic Council is only effective if the resulting science can be transmitted to receptive decision makers. Furthermore, the public will only act if they accurately perceive the causes of climate change and environmental damage (Rakhmanova et al. 2021).

Minorities are the Indigenous Peoples of the Arctic and other residents who are already experiencing environmental change, and particularly climate change (Rakhmanova et al. 2021) that has been imposed on them from activities outside the Arctic. They are conceptually at the centre of the $7 \mathrm{M}$ 's concept as science-based management should prioritise protection of their environment and ecosystem services. Importantly, the Minorities should be totally integrated into all stages of the activities, as observers, researchers, holders of Traditional Knowledge, educators, and managers.

Mother Earth is the part of the concept that explicitly recognises that the Arctic's environment is impacted by activities such as fossil fuel consumption and other types of pollution outside the Arctic while feedbacks from the Arctic's responses to warming affect global climate, sea level rise, transport routes, and access to resources. Recognition is increasing rapidly that the Arctic is becoming the focus of world attention. The Arctic Council, formed in 1996 with 8 member states, 6 Permanent Participants, and 38 Observers is the main focus for this recognition. The right-hand "hemisphere" of the $7 \mathrm{M}$ 's model represents the "Science cooperation" that the Arctic Council seeks to encourage, for example, stimulating more interactions among experts on monitoring, manipulation, and modelling. By better interfacing science with management and working across national borders, "Science diplomacy" is achieved (Berkman et al. 2017) that is critically important as geopolitical tensions and militarisation of the Arctic increase. These tensions result, e.g. from climate change-driven increasing access to resources, such as fossil fuels and rare earth metals, new transport routes such as the northern sea route, national manoeuvring for influence in Greenland, and disputes about navigation routes.

Sustainability of the concept is portrayed by the model's iterative analogy to a simple windmill turning in a clockwise direction. The rotation implies increased knowledge, and more appropriate management at each turn. Thus, monitoring subsequent to a management decision can inform about the effectiveness of the decision as well as "routine" trends in the environment.

\section{CONCLUSIONS}

We have overviewed a mixture of perspective articles, research articles, and reviews of long-term studies by teams of Russian and international researchers published in the Ambio Special Issue on multidisciplinary Siberian environmental change research (Callaghan et al. eds.2021b). The papers are a mixture of descriptive and process-oriented studies grouped to present up-to-date information on environmental networking, ecological processes, biogeochemical processes, biodiversity, and societal consequences of change. Together, the papers give a rare insight into the diversity and complexity of environmental changes occurring over a vast geographical region that has a comparatively small population. These environmental changes are likely to affect the lives of all who live in Siberia and also the global population through important feedbacks to climate, new access routes, and loss of biodiversity: these changes are happening now. We demonstrate that Siberia is rich not only in natural resources but also in rare expertise and important data such as long-term observations. We use "different types of knowing" including observation, experimentation, modelling, Indigenous Knowledge and perceptions of the peoples of both tundra and taiga. However, there are also different degrees of knowing: scientific measurement, local observations, and perceptions. Rationalising these is critical to increasing awareness of climate change impacts to increase take-up of appropriate action on mitigation and adaptation and to increase the relevance of scientific research.

The significant environmental changes in Siberia and their societal impacts, and particularly new records set by extreme weather events in Siberia, should impress on Governments the urgency of acting on carbon emissions. We, therefore, recommend actions based on suggestions in individual papers, and we suggest a model for ensuring better integration among various types of research and management leading to sustainable research and management.

The information we overview is directly relevant to the assessment work of the Arctic Council's working groups such as the "Arctic Monitoring and Assessment Programme", "Conservation of Arctic Flora and Fauna", and Sustainable Development" WGs. It also provides awareness of research, data, and researchers in Siberia to stimulate the Arctic Council's aim to improve science cooperation; by working across borders, it contributes importantly to Science Diplomacy. We emphasise the importance of "Mentoring" to recruit new generations of researchers and managers who can work together more effectively to take better care of planet Earth than previous generations. Already, information from the Special Issue has been converted into educational resources freely 
available (Callaghan et al. 2020c, 2021c). This Special Issue is the start of a process, not the end.

Acknowledgements We are grateful to all the authors of the articles in the Special Issue of Ambio and to Ambassador Korchunov for providing a Preface. We are particularly grateful to Professor Bo Söderström, Editor-in-Chief of Ambio for constant support, encouragement and patience throughout the complex process of bringing together nearly 100 scientists, many of whom do not speak English as their first language. Several people contributed photos and graphics and we thank them. The study was partly carried out using the research equipment of the Unique Research Installation "System of experimental bases located along the latitudinal gradient" TSU with financial support from the Ministry of Education and Science of Russia (RF - 2296.61321X0043, agreement No. 075- 15-2021-672) (http://ckp-rf.ru/usu/586718/; http://www.secnet.online/megaustanovkaru.html) and with financial support of the Russian Foundation for Basic Research, project 18-05-60264 (SK), basic research project 121031300158-9 (EG), Russian Scientific Foundation RSF 20-67-46018 (SK) and TSU Competitiveness Improvement Programme (TVC and OS). Finally, we would like to thank the EU for funding INTERACT (grant agreement 871120) and TSU for support of the Siberian Environmental Change Network SecNET.

\section{REFERENCES}

Abramov I.V. 2017 The Mansi reindeer herding as a strategy of sustenance: Factors of origin and decline. Vestnik Arheologii, Antropologii i Etnografii. 4:104-113. https://doi.org/10.20874/ 2071-0437-2017-39-4-104-113. (in Russian)

Adamenko, M.M., Ya.M. Gutak, and V.A. Antonova. 2017. Climate change and the size of glaciers in the Kuznetsky Alatau Mountains between 1975 and 2015. Led i Sneg. Ice and Snow. https://doi.org/10.15356/2076-6734-2017-3-334-342.

(in Russian).

Åkerman, H.J., and M. Johansson. 2008. Thawing permafrost and thicker active layers in sub-arctic Sweden. Permafrost and Periglacial Processes 19: 279-292.

Akperov, M., W. Zhang, P.A. Miller, I.I. Mokhov, V.A. Semenov, H. Matthes, B. Smith, and A. Rinke. 2021. Responses of Arctic cyclones to biogeophysical feedbacks under future warming scenarios in a regional Earth system model. Environmental Research Letters 16: 064-076.

Aleseev, G.V., M.D. Ananicheva, O.A. Anisimov, I.M. Ashik, MYu. Bardin, E.M. Bogdanova, O.N. Bulygina, VYu. Georgievsky, et al. 2014. Second Roshydromet assessment report on climate change and its consequences in Russian Federation, 56. Moscow: Roshydromet.

Andronov, S., A. Lobanov, A. Popov, Y. Luo, O. Shaduyko, A. Fesyun, L. Lobanova, E. Bogdanova, et al. 2021. Changing diets and traditional lifestyle of Siberian Arctic Indigenous Peoples and effects on health and well-being. Ambio. https://doi.org/10. 1007/s13280-020-01387-9.

Anisimov, O., and S. Zimov. 2021. Thawing permafrost and methane emission in Siberia: Synthesis of observations, reanalysis, and predictive modeling. Ambio. https://doi.org/10.1007/s13280020-01392-y.

Bakker, P., I. Rogozhina, U. Merkel, and M. Prange. 2020. Hypersensitivity of glacial summer temperatures in Siberia. Climate past 16: 371-386. https://doi.org/10.5194/cp-16-3712020.

Bartsch, A., T. Kumpula, B.C. Forbes, and F. Stammler. 2010. Detection of snow surface thawing and refreezing using
QuikSCAT: Implications for reindeer herding. Ecological Applications 20: 2346-2358. https://doi.org/10.1890/09-1927.1.

Berkman, P.A., L. Kullerud, A. Pope, S.N. Vylegzhanin, and O.R. Young. 2017. The Arctic Science Agreement propels science diplomacy. Science 358: 596-598. https://doi.org/10.1126/ science.aaq0890.

Berner, L.T., R. Massey, P. Jantz, B.C. Forbes, M. Macias-Fauria, I. Myers-Smith, T. Kumpula, G. Gauthier, et al. 2020. Summer warming explains widespread but not uniform greening in the Arctic tundra biome. Nature Communications 11: 4621. https:// doi.org/10.1038/s41467-020-18479-5.

Biskaborn, B.K., S.L. Smith, J. Noetzli, H. Matthes, G. Vieira, D.A. Streletskiy, P. Schoeneich, V.E. Romanovsky, et al. 2019. Permafrost is warming at a global scale. Nature Communications 10: 264-278.

Blok, D., M.M.P.D. Heijmans, G. Schaepman-Strub, A.V. Kononov, T.C. Maximov, and F. Berendse. 2010. Shrub expansion may reduce summer permafrost thaw in Siberian tundra. Global Change Biology. 16: 496-507. https://doi.org/10.1111/j.13652486.2009.02110.x.

Bogoyavlensky, V., I. Bogoyavlensky, R. Nikonov, T. Kargina, E. Chuvilin, B. Bukhanov, and A. Umnikov. 2021. New catastrophic gas blowout and giant crater on the Yamal Peninsula in 2020: Results of the expedition and data processing. Geosciences (switzerland) 11: 1-20. https://doi.org/10.3390/ geosciences 11020.

Bokhorst, S., J.W. Bjerke, H. Tömmervik, T.V. Callaghan, and G.K. Phoenix. 2009. Winter warming events damage sub-Arctic vegetation: Consistent evidence from an experimental manipulation and a natural event. Journal of Ecology 97: 1408-1415.

Buldovicz, S.N., V.Z. Khilimonyuk, A.Y. Bychkov, E.N. Ospennikov, S.A. Vorobyev, A.Y. Gunar, E.I. Gorshkov, E.M. Chuvilin, et al. 2018. Cryovolcanism on the Earth: Origin of a Spectacular Crater in the Yamal Peninsula (Russia). Scientific Report 8: 13534. https://doi.org/10.1038/s41598-018-31858-9.

Bulygina, O.N., P.Y. Groisman, V.N. Razuvaev, and N.N. Korshunova. 2011. Changes in snow cover characteristics over Northern Eurasia since 1966. Environmental Research Letters 6: 045204. https://doi.org/10.1088/1748-9326/6/4/045204.

Callaghan, T.V., M. Johansson, Y. Pchelintseva, and S.N. Kirpotin. 2015. Chapter 20. Scientific Cooperation throughout the Arctic: the INTERACT Experience. In The New Arctic, eds. Evengard, B. Nymand Larsen, J. and Øyvind Paasche eds., Vol. 90, 269-289. Springer.

Callaghan, T.V., and O. Shaduyko. 2020. The changing balances within knowledge, experience and wisdom and their roles within decision making: Provocations to stimulate discussion. Partnership of Civilizations (partnerstvo Civilizatsij) 3-4: 289-292. https://doi.org/10.33917/pc.3-4.28-29.2020.

Callaghan, T.V., L. Borilo, and O. Shaduyko. 2020a. SecNet — a new international consortium for understanding and predicting societally-relevant challenges in Siberia. The Arctic Herald. 2: 88-93.

Callaghan, T.V., O. Kulikova, L. Rakhmanova, E. Topp-Jørgensen, N. Labba, L.-A. Kuhmanen, S. Kirpotin, O. Shaduyko, et al. 2020b. Improving dialogue among researchers, local and indigenous peoples and decision-makers to address issues of climate change in the North. Ambio 49: 1161-1178. https://doi. org/10.1007/s13280-019-01277-9.

Callaghan, T.V., H. Savela, and M. Johansson (eds.). 2020c. INTERACT Stories of Arctic Science II. published 2020 by DCE- Department for Environment and Energy, Aarhus University, Denmark, 134 pp. ISBN 978-87-93129-17-7 https://doi.org/ 10.5281/zenodo.4497683

Callaghan, T.V., R. Cazolla Gatti, and G.K. Phoenix. 2021a. The need to understand the stability of Arctic vegetation during rapid 
climate change: An assessment of imbalance in the literature. Ambio. https://doi.org/10.1007/s13280-021-01607-w.

Callaghan, T.V., O. Shaduyko, and S. Kirpotin. 2021. Siberian Environmental Change. Ambio. Special Issue 50.

Callaghan, T.V., H. Savela, and M. Johansson (eds.) 2021c. INTERACTive e-book: Stories of Arctic Science II https:// interactsciencestories.org/

Chapin, F., M. Sturm, M. Serreze, J. McFadden, J. Key, A. Lloyd, et al. 2005. Role of land-surface changes in Arctic summer warming. Science 310: 657.

Christensen, T. R., V. K. Arora, M. Gauss, L. Höglund-Isaksson, and F.-J. W. Parmentier. 2019. Tracing the climate signal: mitigation of anthropogenic methane emissions can outweigh a large Arctic natural emission increase. Nature-Scientific Reports 9:1146-1153.

Cohen, J., X. Zhang, J. Francis, T. Jung, R. Kwok, J. Overland, T.J. Ballinger, U.S. Bhatt, et al. 2019. Divergent consensuses on Arctic amplification influence on mid-latitude severe winter weather. Nature Climate Change 10: 1-10. https://doi.org/10. 1038/s41558-019-0662-y.

Dai, A., D. Luo, M. Song, and J. Liu. 2019. Arctic amplification is caused by sea-ice loss under increasing $\mathrm{CO}_{2}$. Nature Communication 10: 121. https://doi.org/10.1038/s41467-018-07954-9.

De Boeck, H.J., S. Vicca, J. Roy, I. Nijs, A. Milcu, J. Kreyling, A. Jentsch, A. Chabbi, et al. 2015. Global Change Experiments: Challenges and Opportunities. BioScience. https://doi.org/10. 1093/biosci/biv099.

Evseeva, N.S., and T.V. Romashova. 2011. Dangerous meteorological phenomena as an integral part of natural risk (on the example of the south of the Tomsk region). Vestnik of Tomsk State University 353: 199-204 (in Russian).

Feng, S., and Q. Fu. 2013. Expansion of global drylands under a warming climate. Atmospheric Chemistry and Physics 13: 10081-10094. https://doi.org/10.5194/acp-13-10081-2013.

Fedorov, A.N., and P.Y. Konstantinov. 2009. Response of permafrost landscapes of central Yakutia to current changes of climate, and anthropogenic impacts. Geography and Natural Resources. 30: 146-150. https://doi.org/10.1016/j.gnr.2009.06.010.

Forbes, B.C., T. Kumpula, N. Meschtyb, R. Laptander, M. MaciasFauria, P. Zetterberg, M. Verdonen, A. Skarin, et al. 2016. Sea ice, rain-on-snow and tundra reindeer nomadism in Arctic Russia. Biology Letters 12: 20160466. https://doi.org/10.1098/ rsbl.2016.0466.

Frost, G.V., and H.E. Epstein. 2014. Tall shrub and tree expansion in Siberian tundra ecotones since the 1960s. Global Change Biology 20: 1264-1277. https://doi.org/10.1111/gcb.12406.

Frost, G.V., H.E. Epstein, D.A. Walker, G. Matyshak, and K. Ermokhina. 2018. Seasonal and Long-Term Changes to ActiveLayer Temperatures after Tall Shrubland Expansion and Succession in Arctic Tundra. Ecosystems 21: 507-520. https://doi. org/10.1007/s10021-017-0165-5.

Gatti, R.C., T.V. Callaghan, A. Velichevskaya, A. Dudko, L. Fabbio, G. Battippaglia, and J. Liang. 2019. Accelerating upward treeline shift in the Altai Mountains under last-century climate change. Nature Scientific Reports 9: 13. https://doi.org/10.1038/s41598019-44188-1.

Gorbatenko, V.P., V.V. Sevastyanov, D.A. Konstantinova, and O.V. Nosyreva. 2019. Characteristic of the snow cover for the Western Siberia territory. IOP Conference Series: Earth and Environmental Science. 232: 012003. https://doi.org/10.1088/ $1755-1315 / 232 / 1 / 012003$.

Gorbatenko, V.P., I.V. Kuzhevskaya, K.N. Pustovalov, V.V. Chursin, and D.A. Konstantinova. 2020. Assessment of atmospheric convective potential variability in Western Siberia in Changing Climate. Russian Meteorology and Hydrology 45: 360-367. https://doi.org/10.3103/S1068373920050076.
Greve, P., and S.I. Seneviratne. 2015. Assessment of future changes in water availability and aridity. Geophysical Research Letters 42: 5493-5499. https://doi.org/10.1002/2015GL064127.

Groisman, P.Y., T.A. Blyakharchuk, A.V. Chernokulsky, M.M. Arzhanov, L.B. Marchesini, E.G. Bogdanova, I.I. Borzenkova, O.N. Bulygina, et al. 2013. Climate change in Siberia, Ch3 in Groisman, P.Y. and Gutman, G. (Eds.) Regional Environmental Changes in Siberia and Their Global Consequences. Springer Environmental Science and Engineering. https://doi.org/10. 1007/978-94-007-4569-8_3

Gordov, E.P., I.G. Okladnikov, A.G. Titov, N.N. Voropay, A.A. Ryazanova, and V.N. Lykosov. 2018. Development of Information-computational Infrastructure for Modern Climatology. Russian Meteorology and Hydrology 43: 722-728.

Göttel, H., J. Alexander, E. Keup-Thiel, D. Rechid, S. Hagemann, T. Blome, A. Wolf, and D. Jacob. 2008. Influence of changed vegetations fields on regional climate simulations in the Barents Sea Region. Climatic Change 87: 35-50. https://doi.org/10.1007/ s10584-007-9341-5.

Gruber, S. 2012. Derivation and analysis of a high-resolution estimate of global permafrost zonation. The Cryosphere 6: 221-233.

Holzworth, R.H. J.B. Brundell, M.P. McCarthy, A.R. Jacobson, C.J. Rodger, and T.S. Anderson. 2021. Lightning in the Arctic. Geophysical Research Letters 48: e2020GL091366. https://doi. org/10.1029/2020GL091366

Houghton, J.T., G.J. Jenkins, and J.J. Ephraums, eds. 1990. Climate Change: The IPCC Scientific Assessment, 365. Cambridge UK: Press Syndicate of the University of Cambridge.

Ignatova, N.M. 2017. Forced migrations in the framework of the modernization approach. Historical Demography 2: 27-30 (in Russian).

Jansson, J.K., and N. Taş. 2014. The microbial ecology of permafrost. Nature Reviews Microbiology 12: 414-425. https://doi.org/10. 1038/nrmicro3262.

Johansson, M., C. Jonasson, M. Sonesson, and T.R. Christensen. 2012. The man, the myth, the legend: Professor Terry V. Callaghan and his 3M concept. Ambio 41: 175-177. https://doi. org/10.1007/s13280-012-0300-7.

Jensen L. (ed.). 2021. The Sustainable Development Goals Report. New York: UN, 68 p. https://unstats.un.org/sdgs/report/2021

Karlsson, J., S. Serikova, S.N. Vorobyev, G. Rocher-Ros, B. Denfeld, and O.S. Pokrovsky. 2021. Carbon emission from Western Siberian inland waters. Nature Communications 12: 825. https:// doi.org/10.1038/s41467-021-21054-1.

Kharuk, V.I., E.I. Ponomarev, G.A. Ivanova, M.L. Dvinskaya, S.C.P. Coogan, and M.D. Flannigan. 2021. Wildfires in the Siberian taiga. Ambio. https://doi.org/10.1007/s13280-020-01490-x.

Kharyutkina, E.V., S.V. Loginov, E.I. Usova, Y.V. Martynova, and K.N. Pustovalov. 2019. Tendencies in Changes of Climate Extremality in Western Siberia at the End of the XX Century and the Beginning of the XXI Century. Fundamental and Applied Climatology 2: 45-65 (in Russian).

Khromova, T., G. Nosenko, S. Kutuzov, A. Muraviev, and L. Chernova. 2014. Glacier area changes in Northern Eurasia. Environmental Research Letters 9: 015003. https://doi.org/10. 1088/1748-9326/9/1/015003.

Kirpotin, S.N., T.V. Callaghan, A.M. Peregon, A.S. Babenko, D.I. Berman, N.A. Bulakhova, A.A. Byzaakay, T.M. Chernykh, et al. 2021a. Impacts of environmental change on biodiversity and vegetation dynamics in Siberia. Ambio. https://doi.org/10.1007/ s13280-021-01570-6.

Kirpotin, S.N., O.A. Antoshkina, A.E. Berezin, S. Elshehawi, A. Feurdean, E.D. Lapshina, O.S. Pokrovsky, A.M. Peregon, N.M. Semenova, et al. 2021b. How the world's largest peatland helps addressing the world's largest problems. Ambio. https://doi.org/ $10.1007 / \mathrm{s} 13280-021-01520-2$. 
Klyuyev, Y.V., A.A. Kotyukh, and N.V. Olenina. 2008. Cartographic and hydrographic interpretation of the disappearance of Semenovskiy and Vasil'yevskiy Islands in the Laptev Sea. Polar Geography and Geology 6: 114-123. https://doi.org/10.1080/ 10889378209377159.

Korchunov, N.J. 2021. Preface. In Siberian Environmental Change. Ambio Special Issue, eds. T.V. Callaghan, O. Shaduyko, and S.N. Kirpotin. https://doi.org/10.1007/s13280-021-01622-x.

Kosmach, D.A., V.I. Sergienko, O.V. Dudarev, A.V. Kurilenko, O. Gustafsson, I.P. Semiletov, and N.E. Shakhova. 2015. Methane in the surface waters of Northern Eurasian marginal seas. Doklady Akademii Nauk 465: 441-445. https://doi.org/10.1134/ S0012500815120022.

Kozlov, F.A., A.V. Chernokulsky, M.G. Akperov, V.A. Semenov, and A.V. Timazhev. 2019. Influence of atmospheric circulation on characteristics of convective and large-scale precipitation in Northern Eurasia. Proceedings of SPIE-The International Society for Optical Engineering 11208: 112087O.

Lavrillier, A., and S. Gabyshev. 2021. An Indigenous science of the climate change impacts on landscape topography in Siberia. Ambio. https://doi.org/10.1007/s13280-020-01467-w.

Legendre, M., J. Bartoli, L. Shmakova, S. Jeudy, K. Labadie, A. Adrait, M. Lescot, O. Poirot, et al. 2014. Thirty-thousand-yearold distant relative of giant icosahedral DNA viruses with a pandoravirus morphology. Proceedings of the National Academy of Sciences of the United States of America 111: 4274-4279. https://doi.org/10.1073/pnas.1320670111.

Leibman, M.O., A.I. Kizyakov, A.V. Plekhanov, and I.D. Streletskaya. 2014. New permafrost feature-Deep crater in Central Yamal, West Siberia, Russia, as a response to local climate fluctuations. Geography, Environment, Sustainability 7: 68-80.

Lett, S., I.S. Jónsdóttir, A. Becker-Scarpitta, C.T. Christiansen, H. During, F. Ekelund, G.H.R. Henry, S.I. Lang, et al. 2021. Bryophyte functional groups in tundra ecosystems. Arctic Science. https://doi.org/10.1139/AS-2020-0057.

Loginov V. G., M.N. Ignatieva, V.V. Iurak, and I.V. Drozdova. 2020. Drive-in drive-out method of employing people for Arctic oil and gas resources exploration. Izvestiya vysshikh uchebnykh zavedenii. Gornyi zhurnal (News of the Higher Institutions. Mining Journal) 5: 66-79. https://doi.org/10.21440/0536-10282020-5-66-79 (In Russian).

Mallett, J.D.C., J.C. Stroeve, S. Cornish, A.D. Crawford, J.V. Lukovich, M.C. Serreze, A.P. Barrett, W.N. Meier, et al. 2021. Record winter winds in 2020/21 drove exceptional Arctic sea ice transport. Communication Earth and Environment. https://doi. org/10.1038/s43247-021-00221-8.

Matveyeva, N.V., and L.L. Zanokha. 2013. Plant cover stability under significant landscape transformation in Western Taymyr tundras. Trudy Vserossiiskoi nauchnoi konferentsii (Biodiversity of ecosystems of the Far North: inventarization, monitoring, protection). (Syktyvkar, Komi Republik), 3-7 July, 2013. Syktyvkar. Pp. 96-106.

MacDonald, G.M., K.V. Kremenetski, and D.W. Beilman. 2008. Climate change and the northern Russian treeline zone. Philosophical Transactions of the Royal Society b. 363: 2285-2299. https://doi.org/10.1098/rstb.2007.2200.

Meredith, M., M. Sommerkorn, S. Cassotta, C. Derksen, A. Ekaykin, A. Hollowed, G. Kofinas, A. Mackintosh et al. 2019. Polar regions. In IPCC special report on the ccean and cryosphere in a changing climate, IPCC, WMO, UNEP, 1-173.

Minayeva, T., I. Filippov, M.S. Tysiachniouk, A. Markina, S.B. Kisilev, E.D. Lapshina, and A.A. Sirin. 2021. Connecting biodiversity and human dimensions through ecosystem services: the Numto Nature Park in West Siberia. Ambio. https://doi.org/ 10.1007/s13280-021-01625-8.
Mokhov, I.I., M. Akperov, M.A. Prokofyeva, A.V. Timazhev, A.R. Lupo, and H. Le Treut. 2013. Blockings in the Northern hemisphere and Euro-Atlantic region: Estimates of changes from reanalysis data and model simulations. Doklady Earth Sciences. https://doi.org/10.1134/s1028334x13040144.

Myers-Smith, I.H., S.C. Elmendorf, P.S. Beck, M. Wilmking, M. Hallinger, D. Blok, and J.D. Speed. 2015. Climate sensitivity of shrub growth across the tundra biome. Nature Climate Change 5: 887-891.

Myers-Smith, I.H., J.T. Kerby, G.K. Phoenix, J.W. Bjerke, H.E. Epstein, J.J. Assmann, C. John, and L. Andreu-Hayles. 2020. Complexity revealed in the greening of the Arctic. Nature Climate Change 10: 106-117. https://doi.org/10.1038/s41558019-0688-1.

Naumov, I.V., and D.N. Collins, eds. 2006. The History of Siberia. London: Routledge.

Narozhniy, Y., and V. Zemtsov. 2011. Current state of the Altai glaciers (Russia) and trends over the period of instrumental observations. Ambio 40: 575-588. https://doi.org/10.1007/ s13280-011-0166-0.

Orttung, R.W., O. Anisimov, S. Badina, C. Burns, L. Cho, B. DiNapoli, M. Jull, M. Shaiman, et al. 2021. Measuring the sustainability of Russia's Arctic cities. Ambio. https://doi.org/10. 1007/s13280-020-01395-9.

Osipov, E.Y., and O.P. Osipova. 2015. Dynamics of mountain glaciation in the South-Eastern Siberia over the past 160 years. Led $i$ Sneg (Ice and Snow). https://doi.org/10.15356/2076-67342015-2-33-41.[InRussian].

Overland, J.E., and M. Wang. 2021. The 2020 Siberian heat wave. International Journal of Climatology 41: E2341-E2346. https:// doi.org/10.1002/joc.6850.

Panikov, N., P. Flanagan, W. Oechel, M. Mastepanov, and T. Christensen. 2006. Microbial activity in soils frozen to below $-39{ }^{\circ} \mathrm{C}$. Soil Biology and Biochemistry 38: 785-794.

Pascual, D., P. Kuhry, and T. Raudina. 2021. Soil organic carbon storage in a mountain permafrost area of Central Asia (High Altai, Russia). Ambio https://doi.org/10.1007/s13280-02001433-6

Pilyasov, A.N., and V.A. Kibenko. 2020. The entrepreneurship phenomenon in the Yamal reindeer farming: assessment of the situation, paradoxes and contradictions, choice of the future. Arctic: Ecology and Economy 1: 122-137. https://doi.org/10. 25283/2223-4594-2020-1-122-137.(InRussian).

Pollack, H.N., D.Y. Demezhko, A.D. Duchkov, I.V. Golovanova, S. Huang, V.A. Shchapov, and J.E. Smerdon. 2003. Surface temperature trends in Russia over the past five centuries reconstructed from borehole temperatures. Journal of Geophysical Research 108: 2003. https://doi.org/10.1029/2002JB002154.

Popova, A.Y., Y.V. Demina, E.B. Ezhova, A.N. Kulichenko, A.G. Ryazanova, V.V. Maleev, A.A. Ploskireva, I.A. Dyatlov, et al. 2016. Outbreack of Antrax in the Yamalo-Nenets Autonomous District in 2016. https://doi.org/10.21055/0370-1069-2016-4-4246. (in Russian)

Preece, C., T.V. Callaghan, and G.K. Phoenix. 2012. Impacts of winter icing events on the growth, phenology and physiology of sub-Arctic dwarf shrubs. Physiologa Plantarum 146: 460-472.

Pulliainen, J., K. Luojus, C. Derksen, L. Mudryk, J. Lemmetyinen, M. Salminen, J. Ikonen, M. Takala, et al. 2020. Patterns and trends of Northern Hemisphere snow mass from 1980 to 2018. Nature 581: 294-298. https://doi.org/10.1038/s41586-020-2258-0).

Pyak, A.I., S.C. Shaw, A.L. Ebel, A.A. Zverev, J.G. Hodgson, B.D. Wheeler, K.J. Gaston, M.O. Morenko, et al. 2008. Endemic Plants of the Altai Mountain Country, 368. Princeton University Press: Princeton.

Rakhmanova, L., L. Kolesnichenko, I. Kuzhevskaya, I. Kolesnichenko, R. Vorobev, S.V. Tyulyupo, V.Drozdov, and O. 
Shaduyko (Morozova). 2021. Perspectives of climate change. A comparison of scientific understanding and local interpretations by different Western Siberian communities. Ambio. https://doi. org/10.1007/s13280-021-01621-y.

Rees, G., A. Hofgaard, S. Boudreau, D. Cairns, K. Harper, S. Mamet, I.E. Mathisen, Z.M. Swirad, et al. 2020. Is subarctic forest advance able to keep pace with climate change? Global Change Biology 26: 3965-3977. https://doi.org/10.1111/gcb.15113.

Revich, B.A., and M.A. Podolnaya. 2011. Thawing of permafrost may disturb historic cattle burial grounds in East Siberia. Global Health Action 4: 8482. https://doi.org/10.3402/gha.v4i0.8482.

Ryazanova, A.A, and N.N Voropay. 2017. Droughts and Excessive Moisture Events in Southern Siberia. IOP Conf. Ser. Earth Environ. Sci. 96: 012015

Serikova, S., O.S. Pokrovsky, P. Ala-Aho, V. Kazantsev, S.N. Kirpotin, S.G. Kopysov, I.V. Krickov, H. Laudon, et al. 2018. High riverine $\mathrm{CO} 2$ emissions at the permafrost boundary of Western Siberia. Nature Geoscience. 11: 825-829. https://doi. org/10.1038/s41561-018-0218-1.

Savvinov, G.N., P.P. Danilov, A.A. Petrov, V.S. Makarov, V.S. Boeskorov, and S.E. Grigoriev. 2018. Environmental problems of the Verkhoyansky Region. Vestnik North-Eastern Federal University 6: 18-33. https://doi.org/10.25587/SVFU.2018.68. 21798.(InRussian).

Schuur, E.A.G., A.D. McGuire, C. Schädel, G. Grosse, J.W. Harden, D.J. Hayes, C.D. Hugelius, C.D. Koven, et al. 2015. Climate change and the permafrost carbon feedback. Nature 520: 171-179.

Shmakova, L., S. Malavin, N. Iakovenko, T. Vishnivetskaya, D. Shain, M. Plewka, and E. Rivkina. 2021. A living bdelloid rotifer from 24,000-year-old Arctic permafrost. Current Biology 31: 712-713. https://doi.org/10.1016/j.cub.2021.04.077.

Sokolov, A.A., N.A. Sokolova, R.A. Ims, L. Brucker, and D. Ehrich. 2016. Emergent rainy winter warm spells may promote boreal predator expansion into the Arctic. Arctic 69: 121. https://doi. org/10.14430/arctic4559.

Sosnovsky, A.V., N.I. Osokin, and G.A. Chernyakov. 2018. Dynamics of snow storages in forests and fields of Russian plains under climate changes. Led I Sneg (Ice and Snow) 58: 183-190. https:// doi.org/10.15356/2076-6734-2018-2-183-190.(InRussian).

Surazakov, A.B., V.B. Aizen, E.M. Aizen, and S.A. Nikitin. 2007. Glacier changes in the Siberian Altai Mountains, Ob river basin (1952-2006) estimated with high resolution imagery. Environmental Research Letters 2: 045017.

Shumilova, L.V. 1962. Botanical geography of Siberia: 163 . Tomsk: Tomsk State University Press (in Russian)

Steffen, W. 2021. Introducing the Anthropocene: the human epoch. Ambio 50: 1784-1787. https://doi.org/10.1007/s13280-02001489-4.

Titkova, T.B., and V.V. Vinogradova. 2017. Snow occurrence time on the Russia's territory in the early 21 st century (from satellite data). Led I Sneg (Ice and Snow) 57: 25-33. https://doi.org/10. 15356/2076-6734-2017-1-25-33. (in Russian).

Tsyganov, A.N., A. Evgeny, Y.A. Zarov, M.G. Mazei, K.V. Kulkov, S.Y. Babeshko, R.J. Yushkovets, J.L. Payne, et al. 2021. Key periods of peatland development and environmental changes in the middle taiga zone of Western Siberia during the Holocene. Ambio. https://doi.org/10.1007/s13280-021-01545-7.

Vaganov, A., A. Shmakov, and E. Zholnerova. 2021. Red List of Altai Mountain Country (plants). Barnaul: Altai State University, 199 pp. https://doi.org/10.15468/uwre7d

Volkov, I.V., V.A. Zemtsov, A.A. Erofeev, A.S. Babenko, A.I. Volkova, and T.V. Callaghan. 2021. The dynamic land-cover of the Altai Mountains: Perspectives based on past and current environmental and biodiversity changes. Ambio. https://doi.org/ 10.1007/s13280-021-01605-y.
Volkova, I.I., T.V. Callaghan, I.V. Volkov, N.A. Chernova, and A.I. Volkova. 2021. South-Siberian mountain mires: Perspectives on a potentially vulnerable remote source of biodiversity. Ambio. https://doi.org/10.1007/s13280-021-01596-w.

Volkova M.A., N.N. Chered'ko, and A.A. Titovskaya. 2019. Spatiotemporal distribution of periods with low and high temperatures in Western Siberia for 1961-2016. In Proceedings CITES'2019. 64-68. Tomsk: CNTI. (in Russian).

Walter Anthony, K.M., S.A. Zimov, G. Grosse, M.C. Jones, P.M. Anthony, F.S. Chapin III., J.C. Finlay, M.C. Mack, et al. 2014. A shift of thermokarst lakes from carbon sources to sinks during the Holocene epoch. Nature 511: 452-456.

Waits, A., A. Emelyanova, A. Oksanen, K. Abass, and A. Rautio. 2018. Human infectious diseases and the changing climate in the Arctic. Environment International 121: 703-713. https://doi.org/ 10.1016/j.envint.2018.09.042.

Zheleznyak, M.N., M.M. Shatz, S.I. Serikov, R.G. Sysoliatin, Y.B. Skachkov, and V.I. Zhizhin. 2020. Altitudinal geotemperature zonation in Central Altai. Earth's Cryosphere 24: 16-21. https:// doi.org/10.21782/EC2541-9994-2020-3(16-21).

Zhong, X., T. Zhang, S. Kang, and J. Wang. 2021. Spatiotemporal variability of snow cover timing and duration over the Eurasian continent during 1966-2012. Science of the Total Environment 750: 141670

Zhou, J., T. Jiang, Y. Wang, B. Su, H. Tao, J. Qin, and J. Zhai. 2020. Spatiotemporal variations of aridity index over the Belt and Road region under the $1.5^{\circ} \mathrm{C}$ and $2.0^{\circ} \mathrm{C}$ warming scenarios. Journal of Geographical Science 30: 37-52. https://doi.org/10. 1007/s11442-020-1713-z.

Publisher's Note Springer Nature remains neutral with regard to jurisdictional claims in published maps and institutional affiliations.

\section{AUTHOR BIOGRAPHIES}

Terry V. Callaghan (CMG) is a Professor of Arctic Ecology at Sheffield University, UK, and Professor of Botany at Tomsk State University, Russia, is the founder of INTERACT - the international network of terrestrial research stations for research and monitoring in the Arctic and its scientific adviser. He is a co-founder and scientific director of the Siberian Environmental Change Network. His main interests include Arctic Ecology, Climate change, Traditional Indigenous Knowledge, Adaptation and Science Diplomacy.

Address: University of Sheffield UK. University of Sheffield, Alfred Denny Building, Western Bank, Sheffield S10 2TN, UK.

Address: Tomsk State University, 36 Lenin ave., Tomsk, Russia 634050.

e-mail: terry_callaghan@btinternet.com

Olga Shaduyko $(\square)$ is the Director of the Excellence Support Unit of Tomsk State University, Russia. She leads the Siberian Environmental Change Network Secretariat. Her research interests include international collaboration and Siberian research.

Address: Tomsk State University, 36 Lenin ave., Tomsk, Russia 634050.

e-mail: dolcezzamia@mail.ru

Sergey N. Kirpotin is a Professor, Leading Researcher at Tuva State University and Director of the "Bio-Clim-Land" Center of Excellence at Tomsk State University. His research interests include landscape ecology, Arctic studies, geocryology, remote sensing, plant ecology, and biogeochemistry.

Address: Tomsk State University, 36 Lenin ave., Tomsk, Russia 634050 . 
Address: Tuvan State University, Republic of Tuva, 36 Lenina St., Kyzyl, Russia 667000.

e-mail: kirp@mail.tsu.ru

Evgeny Gordov is a Principal Scientist at the Institute of Monitoring of Climatic and Ecological Systems of the Siberian Branch of the Russian Academy of Sciences. His research interests include climate change, long-term monitoring, modelling, and development of thematic IT support.

Address: Institute of Monitoring of Climatic and Ecological Systems, SB RAS, 10/3 Academichesky Pr, Tomsk, Russia 634055.

e-mail: gordov@scert.ru 